RUIZ MUÑOZ, M., «Un apunte crítico sobre la responsabilidad social corporativa (RSC/RSE)», REDUR 9, diciembre 20II, págs. 27-65, ISSN i695-078X

\title{
UN APUNTE CRÍTICO SOBRE LA RESPONSABILIDAD SOCIAL CORPORATIVA (RSC/RSE)
}

\author{
Miguel RUIZ MUÑOZ \\ CATEDRÁTICO ACREDITADO DE DERECHO MERCANTIL \\ UNIVERSIDAD CARLOS III DE MADRID
}

SUMARIO: I. Introducción: Ética empresarial y Responsabilidad Social Corporativa(RSC/RSE). II. LoS negocios y el interés versus la moral y el desinterés: Kant y A. Smith. III. La ética empresarial «es una fuente de beneficios». IV. Ética empresarial y generación de confianza: crisis financiera, exceso de confianza y desconfianza. V. La moral no es un buen instrumento para gobernar la empresa: los peligros de la autorregulación. VI. La ética empresarial como fuente de confusión. VII. Ética empresarial y filosofía moral comunitarista: la extraña paradoja de la Tercera Vía. La Ley es el puente entre la actividad mercantil y la salvación del alma. VIII. El fin de la empresa o de la sociedad: el interés social, la RSC/RSE y la responsabilidad de los administradores. IX. El valor de la ética empresarial: «el poder de la moral será siempre precario».

RESUMEN: El presente trabajo constituye una reflexión crítica sobre la RSC/RSE. Como argumento previo se pone de manifiesto la estrecha conexión entre la RSC/RSE y la ética empresarial. Sentado lo anterior el argumento fundamental del trabajo es la incompatibilidad entre la vida de los negocios, necesariamente interesada, y la moral que debe estar presidida por el desinterés. Y se llega a este convencimiento tanto de la mano de las ideas kantianas como de las de A. Smith. De modo que a juicio del autor difícilmente se puede hablar de que la ética empresarial pueda constituir una fuente de beneficios, ni tampoco que se le pueda considerar como la gran regeneradora de la confianza pérdida en los mercados, porque la moral no es un buen instrumento para gobernar la empresa, sino que por el contrario puede ser más bien causa de confusión en la misma. Es la Ley el cauce adecuado para introducir criterios morales en la gestión de la empresa. Desde un punto de vista jurídicosocietario, la RSC/RSE y los planteamientos éticos que conlleva no son nada fáciles de integrar en la estructura jurídico-organizativa propia del Derecho de sociedades. Especialmente porque la cláusula de «interés social», que sería la vía de posible entrada de la RSC/RSE en la compañía, se acabaría convirtiendo en un cajón de sastre donde todo cabe, lo que daría lugar entre otras cosas a que dicha cláusula perdiese toda su funcionalidad normativa.

Palabras Clave: Responsabilidad Social Corporativa, Responsabilidad Social de la Empresa, ética empresarial, moral, confianza, exceso de confianza, desconfianza, confusión, empresa, sociedad mercantil, interés social, responsabilidad de administradores, grupos de interés, accionistas.

\section{CRITICAL NOTE ON CORPORATE SOCIAL RESPONSABILITY (CSR/RSE)}

ABSTRACT: This work is a critical reflection on CSR/RSE. As a previous argument is highlighted the close connection between CSR/RSE and the business ethics. Sitting above, the fundamental argument of this paper is the incompatibility between the business life necessarily based on interest, and morality that should be chaired by the disinterest. This conviction is reached both by the hand of Kant's ideas as those of A. Smith. So by the author's opinion is hardly speak of that business ethics can be a source of benefits, or that business ethics can regenerate the lost confidence in the markets, because morality is not a good instrument to govern the company, but instead may be more a source of confusion in it. Law is the proper course to introduce moral criteria in the management of the company. From a legal corporate standpoint, CSR/RSE and the ethical considerations involved are not easy to integrate into the own organizational structure of Company Law. Especially because the social» «interest clause, which would be the possible entry pathway of CSR/RSE in the company, eventually transforms in a catch-all where everything fits, which would lead to such a clause would lose all of its functionality as regulation.

KEYWORDS: Corporate Social Responsibility, Social Responsibility of the Company, Business Ethics, morality, trust, overconfidence, distrust, confusion, firm, corporation, corporate interest, liability of directors, stakeholders, shareholders. 


\section{Introducción: Ética empresarial y Responsabilidad Social Corporativa(RSC/RSE)}

Nos preguntamos si debe haber algo más allá de los mandatos legales y de la racionalidad económica, esto es, de la ciencia económica imperante, que dirija la actuación del empresario. Pues bien, de lo que aquí vamos a tratar es de la posible influencia de la moral o de la ética empresarial en la mejora del funcionamiento del sistema económico capitalista en general, y de las empresas en particular. Se habla en este sentido de que existe una preocupación universal por el comportamiento de los directivos, que no se refiere tanto a lo que es legal o ilegal, sino más bien a lo que es correcto o incorrecto, a lo que afecta a las actitudes, a los valores, a la ética en suma. Esta preocupación ha encontrado cierta respuesta en el marco del Gobierno Corporativo en forma de códigos de buen gobierno, de buenas prácticas, de recomendaciones o en términos más generales en las denominadas «normas blandas» (soft law) que promueven el mejor gobierno de las empresas. Y todo este conglomerado de valores y de buenas intenciones se aglutina hoy bajo la denominación genérica de responsabilidad social corporativa o responsabilidad social de la empresa(RSC/RSE). ${ }^{\mathrm{T}}$ La diferencia entre una expresión y otra no es muy relevante, la primera es de origen anglosajón(corporate social responsability) y alude a las corporaciones, estos es, a las grandes compañías cotizadas; y la segunda es propia de la Europa continental y alude de manera más amplia a las empresas en general, parece que de esta manera se quiere dar cabida también a las pequeñas y medianas empresas. La referencia a las corporaciones parece más concorde con la idea de que vivimos en un «sistema corporativo», ni capitalista ni de economía de mercado, que se caracteriza porque es la corporación moderna, la gran Sociedad Anónima, la que domina la economía actual, a pesar de que las alusiones a ello se hacen con cautela o no se hacen, porque como dice Galbraith, los sensibles amigos y beneficiarios del sistema no desean atribuir autoridad definitiva a la corporación, prefieren continuar refiriéndose a las benignas fuerzas del mercado. ${ }^{2}$ En este sentido conviene no perder de vista, y sobre ello volveremos más adelante, que paradójicamente la apelación a la «corporación» refleja y esconde a un mismo tiempo una cierta deslegitimación del Estado, y también de las Organizaciones internacionales, respecto a su capacidad para dictar normas de obligado cumplimiento.

Por RSC/RSE, si bien es un concepto nada claro, ${ }^{3}$ se viene a entender más o menos lo siguiente: «El elemento fundamental de la RSC radica en la implantación dentro de la empresa de la ética empresarial, no como una parte más del negocio, sino como una forma, una actitud y un modo de hacer el negocio mismo, en un momento en el que los clientes y la sociedad demandan de las empresas, no sólo la calidad de sus productos o servicios, sino su comportamiento ético a lo largo de todo el proceso de producción de bienes o servicios». ${ }^{4}$ La Comisión Europea la definía en 200I como: la integración voluntaria por las empresas de las preocupaciones sociales y medioambientales en sus

\footnotetext{
${ }^{\text {I }}$ Cfr. Olcese Santonja, A. (dir.), en Real Academia de Ciencias Económicas y Financieras, dir. A. Olcese Santonja, La Responsabilidad Social de la Empresa (RSE). Propuesta para una nueva economía de la empresa responsable y sostenible, Madrid, junio 2007, p. 35 ss., esp. 46 (www racef.es). Ya en I994 se preguntaba Adela Cortina, en el marco de la ética empresarial, si ¿basta con cumplir con la legalidad vigente para actuar moralmente bien?, a lo que respondía negativamente, porque derecho y moral se complementan, de modo que las leyes son insuficientes para que una sociedad sea justa, o para garantizar que una empresa funcione de una forma justa, de ahí la necesidad de que vengan complementadas por una ética de la empresa («La ética empresarial en el contexto de una ética cívica», en Adela Cortina, dir., Ética de la empresa, Madrid, I994, p. 35 ss., esp. 47-49).

${ }^{2}$ Galbraith, J.K., La economía del fraude inocente. La verdad de nuestro tiempo, tr. esp., Madrid, 2004, p. I725 .

${ }^{3}$ Cfr. Andrews, K., The concept of corporate strategy, Dow Jones Irwin, Inc., Illinois, I97I (citado por Velerdas Peralta, en AAVV, Responsabilidad social de la empresa y Derecho mercantil, Granada, 20Io, p. II y I5).

${ }^{4}$ Vid., entre nosotros, Rivero Torre, «Responsabilidad social corporativa» en AAVV, Responsabilidad social corporativa. Aspectos jurídico-económicos, Castellón de la Plana, 2005, p. 65 ss., esp. 75.
} 
actividades comerciales y en sus relaciones con las partes afectadas. Más recientemente, la misma Comisión nos dice que la RSE se refiere a las acciones de las empresas que van más allá de sus obligaciones jurídicas hacia la sociedad y el medio ambiente, y la define como «la responsabilidad de las empresas por su impacto en la sociedad». ${ }^{5} \mathrm{O}$ también se puede entender, si ponemos más el acento en la organización jurídico-societaria mercantil, como: «La tendencia a exigir de las empresas -principalmente de las grandes corporaciones, sociedades cotizadas o multinacionales- una «conducta» que preste atención a intereses distintos de los de sus accionistas y directa o indirectamente vinculados con su actividad.» ${ }^{6}$ Esto último significa que la RSC, sobre la base de la implantación de los comportamientos éticos que la guían, se constituye en un instrumento conceptual que justifica la extensión ilimitada de la idea de interés social en el seno de las sociedades mercantiles. Y su marco teórico lo constituye la denominada Stakeholders theory, ${ }^{7}$ que postula una nueva visión de la Organización, de la empresa, que como se decía tome en cuenta no sólo los intereses de los accionistas(visión clásica), sino todos los intereses de los sujetos vinculados o afectados por el desarrollo de la actividad empresarial: accionistas, establecimientos financieros, empleados, clientes, suministradores, competidores, instituciones públicas, comunidades locales y la sociedad en su conjunto. ${ }^{8}$ En realidad, y como tendremos ocasión de ver más adelante, con este planteamiento, ya sea de manera consciente o inconsciente, lo que se hace es recuperar la vieja idea institucional del interés social de carácter pluralista(accionistas, trabajadores, consumidores, proveedores, acreedores, ciudadanos en general, etc.) con la finalidad de romper con la idea contractual imperante de carácter monista centrada en los accionistas. ${ }^{9}$

Es más, en última instancia, se puede decir que lo que late de manera más o menos encubierta es la no menos vieja cuestión relativa al alcance del derecho de propiedad, o si se quiere el alcance de la función social de la propiedad bajo el ropaje de la función social de la empresa, ${ }^{\text {IO }}$ o en términos un tanto eufemísticos bajo el camuflaje de la denominada «nueva cultura empresarial». ${ }^{\text {II }}$

${ }^{5}$ Vid. Comunicación de la Comisión al Parlamento Europeo, al Consejo, al Comité Económico y Social Europeo y al Comité de la Regiones: Estrategia renovada de la UE para 2011-2014 sobre la responsabilidad social de las empresas[Bruselas, 25.I0.20II COM (20II) 68I final].

${ }^{6}$ Vid. Sánchez-Calero Guilarte, J., voz «Responsabilidad social corporativa», en Diccionario de Derecho de Sociedades (dir. Alonso Ledesma, C.), Madrid, 2006, p. I023.

7 Vid., especialmente, Freeman, E., Strategic management: A stakeholder approach, Marshfield (Mass.), Pitman Publishing, I984, p. 31 y 46; Donaldson, T./Preston, L.E., The Stakeholder Theory of the Corporation: Concepts, Eviedence, and Implications, Academy of Management Review, 20 (I), I995, p. 65-9I. Y, en la literatura española puede verse, Martínez, JL/Carbonell, M./Agüero, A, Los stakeholders y la acción social de la empresa, Madrid, 2006, p. 25 s.; y Perdiguero, La responsabilidad social de las empresas en un mundo global, Barcelona, 2003, esp. p. I58 ss., esp. I6o, quien nos remite a E. R. Freeman, y nos dice que la empresa no sólo es responsable ante sus accionistas y propietarios, sino también ante sus empleados, los consumidores, sus administradores y el conjunto de los grupos e individuos que son necesarios o que pueden influir en el desarrollo de sus objetivos y en el éxito del proyecto empresarial. De tal modo que la empresa debe ser gestionada en beneficio de todos los individuos y grupos que participan en su desarrollo o pueden verse afectados por sus actividades, lo que obliga a sus gestores a establecer un nuevo equilibrio entre las distintas necesidades, intereses y expectativas que concurren en la empresa, tanto en el nivel interno como en sus relaciones más amplias con la sociedad.

${ }^{8}$ Incluso, lo que resulta más que sorprendente, los grupos terroristas, los seres vivos no racionales, los elementos naturales inanimados y el mismo Dios pueden entrar dentro de esta categoría de los stakeholder (vid. supra nota anterior y cfr. Anquetil, A., Qu'est-ce que l'ethique des affaires, Paris, 2008, p. 2I).

9 Cfr. Esteban Velasco, G., «Interés social, buen gobierno y responsabilidad social corporativa (algunas consideraciones desde una perspectiva jurídico-societaria)», en AAVV, Responsabilidad social corporativa. Aspectos jurídico-económicos, Castelló de la Plana, 2005, p. 47 ss.; Embid Irujo, JM, «La responsabilidad social corporativa ante el Derecho mercantil», CDC, 24, 2004, , p. II Ss., esp. 24 Ss.

Io Vid. Velerdas Peralta, A., «Aproximación jurídica a la responsabilidad social corporativa», en AAVV, Responsabilidad social de la empresa y Derecho mercantil, Granada, 2010, p. 19-24, donde se pone de manifiesto de manera correcta este aspecto, pero donde se incurre, a nuestro juicio, en dos graves excesos de signo un tanto contradictorio. Por un lado se afirma la conexión de la RSC con el triunfo socio-económico del 
En la actualidad la literatura sobre la RSC/RSE es extensísima, sin perjuicio de otras referencias que podamos hacer a lo largo de este trabajo, para una aproximación a las diferentes concepciones de la idea de responsabilidad social corporativa dejamos señaladas algunas referencias. ${ }^{12}$ No obstante, y sin perjuicio de ciertas diferencias,$^{13}$ lo relevante para nosotros es que desde sus orígenes hasta el momento presente siempre aparece presidida por la referencia a los comportamientos éticos. ${ }^{\mathrm{I}}{ }^{\mathrm{Y}} \mathrm{Y}$ así se puede comprobar tanto en los planteamientos teórico ${ }^{15}$ como en los documentos internacionales y nacionales que han ido apareciendo a lo largo de los últimos años. En el denominado Global Compat(Pacto mundial de las Naciones Unidas en materia de responsabilidad social de las empresas, I999-2004), en el Libro Verde de la Comisión Europea titulado Fomentar un marco europeo para la responsabilidad social de las empresas[Bruselas, I8.7.200I, COM(200I) 366 final], y en el Foro de Expertos en RSE del Ministerio de Trabajo y Asuntos Sociales de 2005. ${ }^{16}$ También en el Informe del Congreso de los Diputados para potenciar y promover la responsabilidad social de las empresas. ${ }^{17}$ Más recientemente, en el ámbito comunitario, han aparecido en 2006 la Comunicación de la Comisión al Parlamento Europeo, al Consejo y al Comité Económico y Social Europeo: Poner en práctica la asociación para el crecimiento y el empleo: Hacer de Europa un polo de excelencia de la responsabilidad social de las empresas[Bruselas, 22.3.2006 $\operatorname{COM}(2006)$ I3 6 final]; y en 20II, la Comunicación de la Comisión al Parlamento Europeo, al Consejo, al Comité Económico y Social Europeo y al Comité de la Regiones: Estrategia

Estado social, mientras que por otro se concibe la RSC como reacción ante la paralización (dejación del legislador y del Estado) de la función social de la propiedad. A este respecto conviene no perder de vista dos aspectos, uno que el derecho de propiedad constituye un derecho fundamental que tiene justa cabida en la Convención Europea de Derecho Humanos, aunque sea en su Protocolo Adicional, y como tal es tutelado por el TEDH (Cfr. Aguilera Vaques, M., «El reconocimiento del derecho a la propiedad privada y los límites de su regulación», en AAVV, La Europa de los Derechos: El Convenio Europeo de Derecho Humanos, Madrid, 2005, p. 767 ss.). Y otro, que la vía procedimental desarrollada en algunos de los países más avanzados, como es el caso de Alemania mediante el modelo de «cogestión obrera», no ha estado exento (ni se puede decir que lo esté todavía) de una fuerte polémica que tuvo que resolver finalmente su Tribunal Constitucional. Volveremos sobre estas cuestiones más adelante.

${ }^{\text {II }}$ Cfr., entre otros, Tortosa Cosme, E., «Responsabilidad social de la empresa: un nuevo modelo de empresa», en Papeles de Economía Española, I08, 2006, p. Io6, ss., esp. II3-II5; Velerdas Peralta, A., «Aproximación jurídica a la responsabilidad social corporativa», cit., p. I3; Gond, J-P/Igalens, J., La responsabilité sociale de l'entreprise, $2^{\mathrm{a}}$ ed., Paris, 2010, p. 52-55.

${ }^{\text {I2 }}$ Vid. Oxford Handbook of Corporate Social Responsability, Crane/Matten/McWilliams/Moon/Siegel (ed.), Oxford, Oxford University Press, 2008; Gond, J-P/Igalens, J., La responsabilité sociale de l'entreprise, $2^{\mathrm{a}}$ ed., Paris, 20Io, p. 36 ss.; Capron, M./Quairel-Lanoizelée, F., La responsabilité sociale d'entreprise, Paris, 2007, passim, esp. p. 5-3I. También, la citada y editada por la Real Academia de Ciencias Económicas y Financieras, bajo la dirección de Aldo Olcese Santonja, titulada La Responsabilidad Social de la Empresa (RSE). Propuesta para una nueva economía de la empresa responsable y sostenible, Madrid, junio 2007, un voluminoso trabajo de casi ochocientas páginas.

${ }^{13}$ Nos referimos especialmente a las diferentes concepciones norteamericana y europea, tanto en lo referente a la ubicación del individuo en la sociedad (una más individualista frente a la otra más colectivista, respectivamente), como respecto a la idea del bien general o del bien común (una más confiada al mercado y a la filantropía y la otra más próxima al Estado, respectivamente). Para más detalles puede verse Habisch, A., et al (dir.), Corporate Social Responsability Across Europe, Berlin, 2005, passim; y Capron, M./Quairel-Lanoizelée, F., La responsabilité sociale d'entreprise, Paris, 2007, p. 30-3I.

${ }^{14}$ Vid. Bowen, H.R., Social Responsability of the Businessman, New York, I953, passim, con un claro fundamento religioso. Y así se deja testimonio más modernamente en uno de los capítulos conclusivos del Oxford Handbook of Corporate Social Responsability, Crane/Matten/McWilliams/Moon/Siegel (ed.), Oxford, Oxford University Press, 2008.

${ }^{15}$ Vid., entre otros muchos, R.E. Freeman, «The politics of stakeholders theory: Some future directions», Business Ethics Quarterly, 4 (4), I994, p. 409-42I; Donaldson, T./Preston, L.E., The Stakeholder Theory of the Corporation: Concepts, Eviedence, and Implications, Academy of Management Review, 20 (I), I995, p. 65-9I; R.E. Freeman/K. Martin/B. Parmar, «Stakeholder capitalism», Journal of Business Ethics, 74, 2007, p. 303-3I4.

${ }^{16}$ Una visión de conjunto sobre estos documentos puede verse en Tortosa Cosme, E., «Responsabilidad social de la empresa: un nuevo modelo de empresa», en Papeles de Economía Española, Io8, 2006, p. Io6, ss., esp. II3-II5.

${ }^{17}$ Ministerio de Trabajo y Asuntos Sociales, Madrid, 2007, passim, esp. p. 39-55. 
renovada de la UE para 2011-2014 sobre la responsabilidad social de las empresas[Bruselas, 25.I0.20II COM(20II) 68I final]. En este último documento se habla de una nueva definición de la RSE: la responsabilidad de las empresas por su impacto en la sociedad. Y que se deberá desarrollar un proceso de integración en la empresa de las preocupaciones sociales, medioambientales y éticas, el respeto de los derechos humanos y las preocupaciones de los consumidores. Además, se añade algo que a nuestro juicio resulta un tanto sorprendente, que el respeto a la legislación aplicable y el de los convenios colectivos constituye un requisito previo de la RSE.

Pues bien, es justamente en este aspecto ético en el que queremos incidir, con la finalidad de poner de manifiesto que no resulta del todo correcto hablar de que el recurso a ciertos principios éticos o morales por los gestores empresariales redundarán en beneficio del interés de la compañía. Y no es correcto a nuestro juicio porque como enseguida veremos la moral es en sí misma desinteresada, de modo que todo comportamiento interesado carece de valor moral.

Moral y ética si bien no son necesariamente lo mismo, aquí las vamos a considerar -como por otra parte es habitual-como equivalentes, ${ }^{18}$ pues en todo caso, como se nos dice, se complementan(deber y amor, respectivamente); si bien es cierto que la ética es una noción más amplia que incluye a la moral y es la fundamental, porque nos indica el camino hacia la vida buena. ${ }^{19}$

Hay que decir que estamos en el ámbito de la ética privada que, como tiene escrito el profesor G. Peces-Barba, ${ }^{20}$ es una ética material y de contenidos, que desarrolla modelos de conducta o de comportamiento, estrategias de felicidad, o ideales sobre el bien y la virtud, lo que él denomina contenido de planes de vida que se ofrecen a los posibles destinatarios de los mismos. A diferencia de la ética pública, que es formal y procedimental, que tiene por finalidad configurar una organización política y jurídica, donde cada uno pueda establecer libremente sus planes de vida o elegir entre aquellos proyectos de planes de vida institucionalizados, por un grupo social, por una Iglesia o por una escuela filosófica. De manera que -nos sigue diciendo- la libertad inicial o de elección tiene una organización política y jurídica, inspirada y fundada en el valor de la libertad social, a lo que completan y matizan, la seguridad, la igualdad y la solidaridad, que permite llegar a las personas a abordar el ideal de la autonomía o libertad moral. Pero bien entendido que estos dos ámbitos de la ética hunden sus raíces en la ética individual o personal, porque no hay otros sujetos morales que los individuos. ${ }^{2 \mathrm{~T}} \mathrm{Y}$ ambas éticas deben ser compatibles. Para ello es necesario que la ética privada se someta a una serie de condiciones o presupuestos. Primero que no sea una oferta excluyente, sino que se produzca en un contexto pluralista en concurrencia con otras ofertas, que acepte el juego limpio y la lealtad al sistema. Segundo que el seguimiento sea en ejercicio de la autonomía personal y de la libertad de elección. Y tercero que sea posible construirse un plan de vida distinto, siempre y cuando que sea universalizable como oferta a los demás para que estemos en el ámbito moral. En definitiva, sin los requisitos de universalidad y de autonomía no hay moralidad privada. Lo que constituye una clara referencia kantiana. Y termina diciéndonos: «Cuando una moralidad privada coincide siempre con los intereses de su titular, hay grandes motivos para sospechar que

\footnotetext{
${ }^{\text {I8 }}$ Cfr. Tourneau, Ph. Le, «Existe-t-il une morale des affaires ?», en AAVV, La morale et le droit des affaires, Paris, I996, p. 7 ss.

I9 Cfr. Comte-Sponville, A., Diccionario filosófico, tr. esp., Barcelona, 2005, p. 205-206; idem, El capitalismo, ¿Es moral?, tr. esp., Barcelona, 2004, p. 78 ss.

${ }^{20}$ Peces-Barba, G., «Etica, Política y Derecho: El paradigma de la modernidad», en Etica pública y Derecho, Real Academia de Ciencias Morales y Políticas, Discurso de recepción, Madrid, I993, p. II-46, esp. 28-3I.

${ }^{2 \pi}$ Sobre la ética pública puede verse Muguerza, J., «Etica púbica, derechos humanos y cosmopolitismo», en Gómez/Muguerza (eds.), La aventura de la moralidad (Paradigmas, fronteras y problemas de la ética), Madrid, 2007, p. 510 ss.
} 
esa persona carece de moralidad.» En conclusión, a nuestro juicio, no se hace otra cosa que plantear la necesaria correlación entre la moral y el desinterés, que constituye la base argumental del presente trabajo y a lo que nos vamos a referir a continuación.

\section{Los negocios y el interés versus la moral y el desinterés: Kant y A. Smith}

Con la llamada que de manera recurrente se produce en los últimos tiempos a la ética empresarial estamos ante el retorno a la moral. Hasta el punto de que se habla incluso de la rentabilidad de la ética(la ética es eficiente, la ética vende: Ethics pays): ser ético es rentable. ${ }^{22}$ Se trata de la fusión imposible entre la ética y el marketing, que algunos han llegado a dar nombre propio como markética. ${ }^{23}$ Todo esto resulta enormemente chocante. Porque hablar de la rentabilidad de la ética supone internalizarla y computarla como uno de los elementos necesarios para la consecución del fin primordial de la empresa que es el beneficio, sin perjuicio de que la idea de beneficio se pueda articular sin ningún problema con el fin de la supervivencia y, si se quiere, incluso con el principio de desarrollo sostenible. ${ }^{24}$ Pero en cualquier caso no parece que deban caber muchas dudas respecto a lo que constituye la motivación fundamental del empresario, su máximo interés, como es la finalidad lucrativa, porque es lo que mejor responde al sistema económico capitalista en el que estamos. ${ }^{25} \mathrm{Y}$ dicho esto sin perjuicio de que situados en el modelo del Estado

${ }^{22}$ Así, desde hace algunos años, en el ámbito de la filosofía jurídica, moral y política, como es el caso de Adela Cortina (cit., I994, p. 50). Y entre los juristas españoles se puede ver a Embid Irujo, JM («La responsabilidad social corporativa ante el Derecho mercantil», Cuaderno de Derecho y Comercio, 24, 2004, p. II ss., esp. I5-2I y 36 ss.; idem, «Derecho, mercado y responsabilidad social corporativa», en Papeles de Economía Española, Io8, 2006, p. 63-74, esp. 63-66), que nos dice, entre otras cosas, que el propósito de reforzar la legitimidad de la empresa (y de la Economía de mercado) es el objetivo básico de la RSC, legitimidad que al parecer está en entredicho a consecuencia de los últimos escándalos económicos producidos. A lo que añade, que con la RSC no se trata de meras fórmulas sugestivas, sino de un verdadero plan estratégico con repercusiones positivas en la competitividad de la empresa y en su reputación. Así como que la idea de ser calificada como «empresa socialmente responsable» se configura de este modo como un elemento prestigioso, a la par que rentable, desde la perspectiva concreta de una empresa que aspire a una implantación satisfactoria en el mercado.

${ }^{23}$ Vid., en sentido crítico, con quien coincidimos, Comte-Sponville, A., El capitalismo, ¿Es moral?, tr. esp., Barcelona, 2004, p. 49 ss. También en igual sentido crítico, Lipovetsky, G., Metamorfosis de la cultura liberal. Etica, medios de comunicación y empresa, tr. esp. Barcelona, 2003, p. 68-7i; Giner, S., El futuro del capitalismo, Barcelona, 2010, p. II4-II6.

${ }^{24}$ Básicamente la sostenibilidad lo que significa es el compromiso con las generaciones futuras, tal y como se expresa en el art. 20 a de la Ley Fundamental (GG) de la República de Alemania en su reforma de I994. Y así lo podemos ver ahora entre nosotros en el art. 2 de la nueva Ley de economía sostenible 2/20II (BOE, 5 de marzo de 20II). Pero hay una importante diferencia sobre la formulación legal en un caso y en otro, en el primero se integra en su sistema jurídico constitucional y en el caso español en una ley ordinaria. A nuestro juicio, resulta más acertada la incorporación constitucional por dos razones, tanto por la índole genérica del bien jurídico protegido, como porque es desde la constitución como mejor se puede integrar el nuevo principio en el ordenamiento jurídico. En este sentido el citado precepto constitucional alemán finaliza de un modo clarificador con la delimitación de la capacidad de actuación de dicho principio: «en las condiciones fijadas por la ley y el derecho». Obsérvese que de esta manera se resuelven un gran número de conflictos, porque es la ley (y el derecho) en cada caso, criterio de oportunidad política, la que determinará el grado de tutela o de desarrollo del principio de sostenibilidad. A lo que hay que añadir que se parte de un concepto arraigado de Estado de Derecho Ecológico y del sustento en un fuerte componente jurídico-procedimental y planificador (Cfr. Kahl, W., «La Administración en el Estado de Derecho de Alemania: entre la tradición y el cambio», El Cronista, Io, febrero20Io, p. 68 ss., esp. 76-77). En el caso español la cuestión se presenta algo más complicada, porque a partir de ahora se dejan abiertos un sin fin de conflictos normativos de orden valorativo dado que estamos ante disposiciones legales de un mismo rango, y sin que los clásicos principios de lex posterior derogat priori o specialia generalibus derogat puedan resolver fácilmente todos los problemas que se puedan presentar. En todo caso la solución de los posibles conflictos de leyes debe estar presidido por la necesaria coordinación de los mandatos constitucionales de los artículos 45 y 38 (libertad de empresa), a la vista de la diferente graduación tutelar establecida por el artículo 53 de la misma Constitución y del principio de proporcionalidad.

${ }^{25}$ Cfr. Giner, S., cit., p. ıा6. 
social(Estado de Bienestar), podamos hablar de una economía social de mercado. ${ }^{26}$ Sobre esto se ha escrito mucho y no pretendemos ahora entrar en un campo tan amplio que nos supera y nos distraiga de nuestro objetivo principal, pero conviene tener siempre presente que los motivos del Estado de bienestar estaban lejos de ser altruistas, sino que más bien constituían un instrumento para alcanzar el poder, dado que, en una situación de casi sufragio universal, el número de pobre superaba al de ricos. ${ }^{27}$

Lo anterior, promover que la ética es rentable, significa que la utilización de la moral es en todo caso una utilización interesada, algo que no es propio de la misma, porque lo propio de la moral es el desinterés. De esta manera lo que se produce es una grave confusión de planos o de órdenes, se confunden el orden técnico-empresarial o económico con el orden moral, cuando ambos responden a reglas o principios distintos. ${ }^{28} \mathrm{La}$ ética empresarial, y su principal baluarte actual, como es la RSC/RSE, no deja de ser una moda, que como todas las modas está sometida al fenómeno del eterno retorno, y que por la misma razón es generadora de confusión $^{29}$ y de inseguridad, lo que sin duda no se compadece bien con la necesaria seguridad de los tráficos mercantiles. Y hay que recordar aquí que la confusión no es nunca generadora de confianza, por lo que resulta más que paradójico que, como suele suceder, se pretenda justificar la ética empresarial desde la necesidad o la conveniencia de aportar mayor confianza a la actividad empresarial. ${ }^{30}$ Téngase en cuenta que por lo que se refiere a la cuestión temporal, esta «moda» de la ética de los negocios («Ethical Chic»)no es tan reciente, sino que viene calando lenta e imperceptiblemente nuestras mentalidades desde hace algunos años, concretamente desde los años ochenta del pasado siglo en los Estados Unidos y en la década sucesiva en Europa. ${ }^{3{ }^{1}}$

No obstante, lo cierto es que se pueden producir coincidencias de motivaciones morales y de otro tipo, y es precisamente en estos supuestos de doble motivación, donde la cuestión se presenta con algo más de dificultad. Para intentar resolverla acudimos al gran filósofo de la moral que es Immanuel Kant. Lo relevante para el filósofo alemán para calificar una acción como moralmente valiosa es que el motivo sea el cumplimiento de un deber moral que nos viene impuesto desde nuestro interior por la razón, no es suficiente

${ }^{26}$ Sobre estos conceptos, diferentes, pero con tendencia al solapamiento, y su evolución en tiempos recientes nos remitimos a Sotelo, I., El Estado social. Antecedentes, origen, desarrollo y declive, Madrid, 20ıo, passim, esp. 267 ss., y 395.

${ }^{27}$ Cfr. Ferguson, N., El triunfo del dinero. Como las finanzas mueven el mundo, tr. esp., Barcelona, 2009, p. 2I8-220. También Sotelo, I., El Estado social. Antecedentes, origen, desarrollo y declive, Madrid, 20IO, p. 287, que habla de que la conjunción de la gran empresa con el Estado para amainar la lucha de clases de modo que no amenace la paz social, ha estado, y sigue estando, en la base del Estado social. De este modo W. Rathenau (el padre de la doctrina de la Unternehmen an sich) hablaba en el período de entreguerras del Estado social como «nuestro destino». Y algo no muy distinto sucede hoy en los países que empiezan a industrializarse. En el caso de la China comunista convertida al capitalismo el papel de las empresas multinacionales resulta clarividente. Y si nos remontamos en el tiempo, podemos observar la conversión por el liberalismo de las antiguas instituciones de la caridad cristiana en fórmulas secularizadas bajo el apelativo de la solidaridad.

${ }^{28}$ Vid. Comte-Sponville, El capitalismo, ¿Es moral?, tr. esp., Barcelona, 2004, p. 57 ss.

${ }^{29}$ Vid. Comte-Sponville, El capitalismo, cit., p. 50 ss.

${ }^{30}$ Cfr., si bien no con planteamientos similares, Cortina Orts, A., «La responsabilidad social corporativa y la ética empresarial», en AAVV, Mitos y realidades de la Responsabilidad Social Corporativa en España. Un enfoque multidisciplinar, Cizur Menor, 2006, p. II7-II8; y Argandoña, A., «Economía de mercado y responsabilidad social corporativa», en Papeles de Economía Española, ıo8, 2006, p. 5.

${ }^{31}$ Cfr. Etzioni, A., The Moral Dimension: Toward a New Economics, Nueva York, I988, passim; Lipovetsky, G., El crepúsculo del deber. La ética indolora de los nuevos tiempos democráticos, tr. esp., Barcelona, I994, p. 246-247; Tourneau, Ph. Le, «Existe-t-il une morale des affaires ?», en AAVV, La morale et le droit des affaires, Paris, I996, p. 7 Ss.). Entre los juristas españoles puede verse, más recientemente, Embid Irujo, JM, «La responsabilidad social ...», cit., p. II Ss., esp. 42, donde nos dice: «Como todas la modas, y la RSC, en nuestros días, merece gozar de ese calificativo, encontramos en el propósito, tan generalizado, de configurar empresas «socialmente responsables» una subordinación a los imperativos del momento, sin duda, pero también una forma de encadenar ciertas pretensiones sociales con planteamientos más clásicos que se creían, hasta hace poco, plenamente superados.» 
que sea conforme a la ley moral, de modo que si resulta coincidente con el interés propio o con cualquier otro «motivo de inclinación» (necesidades, deseos, preferencias o apetitos), carecerá ya de valor moral. ${ }^{32}$ Lo importante son los motivos y no las consecuencias. ${ }^{33}$ Para ejemplificar la diferencia entre el deber y la inclinación Kant nos trae a colación la figura de un comerciante, concretamente al que él denomina un comerciante avispado(avisado, avezado o prudente), que sólo es honrado para conservar a sus clientes. Lo podemos ver en una de sus obras fundamentales, la Fundamentación de la Metafísica de las Costumbres, donde Kant busca el «principio supremo de moralidad», ${ }^{34}$ y nos dice lo siguiente:

«Por ejemplo, es conforme al deber, desde luego, que el comerciante no cobre más caro a un comprador inexperto, y en los sitios donde hay mucho comercio el comerciante avispado no lo hace, en efecto, sino que mantiene un precio fijo para todos en general, de forma que un niño puede comprar en su tienda tan bien como otro cualquiera. Así pues, uno es servido honradamente, pero esto no es ni mucho menos suficiente para creer que el comerciante haya obrado así por deber o por principios de honradez: lo exigía su provecho. Tampoco es posible admitir además que el comerciante tenga una inclinación inmediata hacia los compradores, de manera que por amor a ellos, por decirlo así, no haga diferencias a ninguno en el precio. Por consiguiente, la acción no ha sucedido ni por deber ni por inclinación inmediata, sino simplemente con una intención egoísta.» ${ }^{35}$

Se trata de un sujeto[el comerciante] de una honradez intachable, pero como dice Kant, actúa conforme a la moral y conforme al deber, efectivamente, ¿y cuál es su deber? Ser honrado, y efectivamente es honrado, continúa diciéndonos, y actúa conforme al deber, pero no por deber. Sino que actúa conforme al deber, pero por interés, porque de lo contrario dicho comerciantes es plenamente consciente de que «la primera fullería descubierta le haría perder clientes» y por consiguiente dinero. Y bien, concluye Kant, en este caso, por conforme que sea a la moral, su acción carece de todo valor moral. Porque se realiza por interés, y lo propio del valor moral de una acción es el desinterés, no el interés. ${ }^{36}$

Las afirmaciones de Kant se corroboran a la perfección si nos aproximamos a su gran contemporáneo en el campo de la economía, aunque también de la moral, como lo fue Adam Smith. Este, como uno se puede imaginar, no duda en apelar al interés propio del comerciante -su egoísmo- que, como es sabido, constituyó la piedra angular que permitió fundar el capitalismo y que dio paso a la revolución industrial. ${ }^{37}$ En un conocido párrafo probablemente el que más- de La Riqueza de las Naciones nos dice que la satisfacción de nuestras necesidades hay que buscarla más en el interés ajeno que en su benevolencia o caridad:

${ }^{32}$ Cfr. Comte-Sponville, El capitalismo, cit., p. 53.

33 Vid. Sandel, M.J., Justicia. ¿Hacemos lo que debemos?, tr. esp., Barcelona, 20II, p. I29-I30.

34 Una breve indagación sobre este principio puede verse en Sandel, M.J., cit., p. I35 sS.

${ }^{35}$ Kant, I., Fundamentación de la metafísica de las costumbres[I785], tr. esp., ed. de Luis Martínez de Velasco, Austral, i6 a ed., Madrid, 2004, p. 59.

${ }^{36}$ Cfr. Comte-Sponville, A., El capitalismo, cit., p.53-55; MacIntyre, A., Historía de la ética, tr. esp., Barcelona, 2006, p. 209; Rawls, J., Lecciones sobre la historia de la filosofía moral, tr. esp., Barcelona, 2007, p. 228-23I; Sandel, M.J., Justicia, cit., p. I30-I3I. No podemos entrar ahora en mayores detalles sobre esta tesis kantiana, que asumimos, pero dejamos constancia de que fue criticada en su momento por A. Schopenhauer en su Escrito concursante sobre el fundamento de la moral[1839-I840] (Los dos problemas fundamentales de la ética, con introducción y notas de Pilar López de Santa María, tr. esp., $4^{a}$ ed., Madrid, 2009, esp. xxxii-xxxix, y I57 Ss.). Para una primera aproximación actualizada a esta visión crítica de Schopenhauer nos remitimos a Rifkin, J., La civilización empática. La carrera hacia una conciencia global en un mundo en crisis, tr. esp., Madrid, 20Io, p. 334-338).

${ }^{37}$ Cfr. Galbraith, J.K., Historia de la economía, tr. esp., Barcelona, I989, p. 77-78. 
«No es la benevolencia del carnicero, del cervecero o del panadero la que nos procura el alimento, sino la consideración de su propio interés. No invocamos sus sentimientos humanitarios sino su egoísmo; ni les hablamos de nuestras necesidades, sino de sus ventajas. Sólo un mendigo depende principalmente de la benevolencia de sus conciudadanos; pero no en absoluto. $»^{8}$

Este texto no está muy alejado de lo que acabamos de leer del filósofo alemán, en ambos casos se deja claro que el comercio se rige sobre la base de comportamientos interesados, que la moral no forma parte de las actuaciones mercantiles. Y que está bien que sea así. Pero resulta evidente que también hay una clara diferencia entre ambos textos, fundamentalmente, a nuestro juicio, en el diferente enfoque desde el que se parte en un caso y en otro. Porque mientras en el primero se parte de la contraposición entre el deber y las inclinaciones que fundamentan nuestras acciones, de manera que la «voluntad buena» es aquella que lleva a cabo sus acciones por deber y no a causa de las inclinaciones y, caso de coincidencia, como nos ejemplifica con el estereotipo del comerciante avispado o prudente, el deber[moral] pasa a un segundo plano, queda oculto, solapado por la inclinación del interés, hasta el punto de que se diluye y prácticamente desaparece. Se razona por tanto de un modo deductivo, se va de lo general a lo particular. Por el contrario, en el texto de A. Smith, estamos claramente ante un caso particular, del mismo tenor que el planteado por Kant, como es el comportamiento interesado de un comerciante, que desarrolla al hilo del principio que motiva la división del trabajo, que es a su vez causa principal de la riqueza(Capítulo II del Libro Primero de $L a$ Riqueza), ${ }^{39}$ y que no es otro a su juicio que el egoísmo o la persecución del propio interés. No hay aquí por tanto alusión al deber moral, a los posibles comportamientos desinteresados, si bien eso no significa que no los reconozca y los admita, sino que por el contrario es una cuestión que, a su modo, ya ha dejado resuelta en su otra gran obra sobre filosofía moral que precede bastante en el tiempo a la más conocida sobre La Riqueza de las Naciones[1776]. Efectivamente, A. Smith, en La Teoría de los sentimientos morales[I759], aborda estas cuestiones desde un principio, en el primer párrafo de la obra[Parte I, Sección I, I(De la simpatía)], donde se dice lo siguiente:

«Por más egoísta que se pueda suponer al hombre, existen evidentemente en su naturaleza algunos principios que le hacen interesarse por la suerte de otros, y hacen que la felicidad de éstos le resulte necesaria, aunque no derive de ella nada más que el placer de contemplarla.» ${ }^{40}$

Estos dos párrafos smithianos pueden resultar aparentemente contradictorios, el interés frente al desinterés, o el egoísmo frente a la generosidad, y hasta tal punto esto ha sido entendido así, que dio lugar ya en el siglo XIX, especialmente en Alemania, al denominado Das Adam Smith Problem..$^{4}$ Se ha discutido si estamos ante un pensador deductivo o inductivo, para terminar en parte calificándolo como un pensador confuso. Modernamente las apreciaciones son más ecuánimes y se impone una visión más coherente sobre su obra. ${ }^{42}$ En este sentido, se viene a decir hoy día que en La Teoría de los sentimientos morales no se realiza ninguna condena del egoísmo, pero que, en todo caso, de lo que no cabe ninguna duda es que la aprobación moral de los actos no tiene nada que ver con el interés individual o el egoísmo. De esta manera el pensador escocés se distancia

${ }^{38}$ Smith, A., Investigación sobre la naturaleza y causas de la riqueza de las naciones[1776], tr. esp., México, FCE, sexta reimpresión, I990, p. I7

${ }^{39}$ Cfr. Galbraith, J.K., Historia de la economía, tr. esp., Barcelona, I989, p. 73.

$4^{\circ}$ Smith, A., Teoría de los sentimientos morales[1759], tr. esp., edición de C. Rodríguez Braun, Madrid, I997, p. 49.

${ }^{4 \mathrm{I}}$ Cfr. Rodríguez Braun, C., «Estudio preliminar», en Smith, A., Teoría de los sentimientos morales[I759], tr. esp., edición de C. Rodríguez Braun, Madrid, I997, p. 20-23; Mendez Baiges, V., Adam Smith. Vida, pensamiento y obra, Navarra, 2007, p. IOO-IOI y I70-I7I.

${ }^{42}$ Ibid. 
claramente de conocidos autores, como Hobbes y Mandeville, ${ }^{43}$ que mantenían esa conexión. ${ }^{44} \mathrm{Y}$, fundamentalmente, leída su obra como un todo, se salva la coherencia de su discurso. De manera que se distingue claramente el plano moral, por un lado, en La Teoría, descontaminado de egoísmo; y por otro, el plano económico, en La Riqueza, presidido por el interés. En la primera de estas obras ya nos anticipa esta distinción de planos cuando nos habla de una sociedad de personas distintas como la de los comerciantes, regida por la utilidad $y$ no por el amor o el afecto mutuo; 45 una idea que luego se verá corroborada en su obra más conocida desde el inicio de la misma, como hemos visto. Pero es más, en su segunda obra, nos dice de manera casi literal que es falsa la pretensión de comerciar por razones de interés público: Jamás he sabido que hagan mucho bien aquellos que simulan el propósito de comerciar por el bien común. Por cierto que no se trata de una pretensión muy común entre los mercaderes, $y$ no hace falta emplear muchas palabras para persuadirlos de ella. ${ }^{6}$ Probablemente, el distanciamiento en el tiempo entre ambas obras, así como la falta de un claro nexo de unión de la segunda con la primera, es lo que ha podido provocar buena parte de las críticas vertidas sobre este punto a la obra de Adam Smith.

En definitiva, a nuestro juicio, se puede hablar, sino de coincidencia entre ambos pensadores, si al menos de una gran aproximación, ${ }^{47}$ porque como decimos se separan ambos planos, moral y económico, de modo que la moral no puede integrarse en los negocios que se caracterizan claramente por el interés. Los comportamientos morales o éticos sólo pueden estar presentes allí donde brille el desinterés, donde la acción sólo esté guiada por un deber moral sin otros impulsos que la motiven. Adam Smith sólo lo apunta, frente a la apabullante y perturbadora tesis de Mandeville(los vicios privados hacen la prosperidad pública), y Kant lo afirma con rotundidad, desde una visión más abstracta, en su camino hacia el imperativo categórico, esto es, hacia el deber moral incondicional, que se universaliza y que por esta misma razón pospone los intereses propios a los de los demás. ${ }^{48}$

\section{La ética empresarial «es una fuente de beneficios»}

A la ética empresarial le sucede algo muy similar al ejemplo planteado por Kant. Que si bien las acciones empresariales que se enmarcan dentro de la misma podríamos considerarlas conformes a la moral, sin embargo no se hacen desinteresadamente, sino por

${ }^{43}$ Mandeville, B., La fábula de las abejas (o Los vicios privados hacen la prosperidad pública)[I729], Comentario crítico, histórico y explicativo de F.B. Kaye, tr. esp., FCE, Madrid, I997. Nos remitimos especialmente al comentario de Kaye para una primera aproximación a esta provocadora y perturbadora obra. A. Smith, buen conocedor de La fábula de las abejas, le dedica unos comentarios críticos en La Teoría de los sentimientos morales cuando se ocupa de los sistemas licenciosos (p. 536-544).

44 Cfr. Mendez Baiges, V., Adam Smith. Vida, pensamiento y obra, Navarra, 2007, p. IOI.

45 «Pero aunque la asistencia necesaria no sea prestada por esos motivos tan generosos y desinteresados, aunque entre los distintos miembros de la sociedad no haya amor y afecto recíproco, la sociedad, aunque menos feliz y grata, no necesariamente será disuelta. La sociedad de personas distintas puede subsistir, como la de comerciantes distintos, en razón de su utilidad, sin ningún amor o afecto mutuo; y aunque en ella ninguna persona debe favor alguno o está en deuda de gratitud con nadie, la sociedad podría sostenerse a través de un intercambio mercenario de buenos oficios de acuerdo con una evaluación consensuada.» (Smith, A., Teoría de los sentimientos morales[1759], tr. esp., edición de C. Rodríguez Braun, Madrid, ı997, p. I85-I86).

${ }^{46}$ Smith, A., Investigación sobre la naturaleza y causas de la riqueza de las naciones[I776], tr. esp., México, FCE, sexta reimpresión, I990, p. 402 (Cfr. Galbraith, J.K., Historia de la economía, tr. esp., Barcelona, I989, p. 77-78).

47 Sobre la posible influencia de uno sobre otro, Rodríguez Braun, C. («Estudio preliminar», en Smith, A., Teoría de los sentimientos morales[I759], tr. esp., edición de C. Rodríguez Braun, Madrid, I997, p. I6) habla de una cierta influencia de A. Smith sobre Kant. En este mismo sentido se manifiesta más recientemente Amartya Sen que afirma con datos relevantes la más que probable influencia de A. Smith en Kant (Sen, A., La idea de la justicia, tr. esp., Madrid, 20IO, p. I53).

${ }^{48}$ Vid. Sandel, M.J., Justicia, cit., p. I4O. 
interés, porque resultan beneficiosas para la empresa. En definitiva se internalizan, ${ }^{49}$ se integran en la gestión empresarial ${ }^{\circ \circ}$ o en el marketing de la empresa con la finalidad de rentabilizar su coste. Luego difícilmente se puede sostener que en estos casos, por lo general, se trate de comportamientos morales o éticos, porque no brilla el desinterés, sino más bien un claro interés por las cosas propias. Hasta tal punto es así, que las grandes escuelas de negocios «venden», entre sus nuevos «productos estrella», a precios más que respetables, master o cursos de formación para directivos sobre «Gestión empresarial de la ética de los negocios», y lo hacen bajo la pancarta publicitaria de que «La ética es una fuente de beneficios». Como se nos dice, esta pretensión de que la ética sirva para todo, acaba por diluirla e instrumentalizarla hasta tal punto que ya no está presente de verdad en ninguna parte..$^{\mathrm{II}}$ Además de que no está nada claro, que las políticas empresariales de RSC/RSE consigan maximizar el valor como en las demás empresas. Y en el caso de generalizarse este tipo de políticas empresariales desaparecerían las posibles ventajas comparativas. ${ }^{52}$

Los defensores de la ética empresarial son conscientes de sus propias limitaciones. De que la ética «vende», de que es utilizada o manipulada con la simple finalidad de servir como reclamo. O también como un ejercicio de competencia entre las empresas, que se afanan por aparecer en los rankings más prestigiosos de las empresas socialmente responsables. Esto les lleva a sus defensores a rechazar que la responsabilidad social de la empresa pueda consistir en este tipo de competencia febril, que tiene por finalidad generar capital, simpatía y buena reputación. Y para sacarla del marasmo en el que han metido a la ética, se nos dice que la responsabilidad social debe asumirse como una herramienta de gestión, como una medida de prudencia y como una exigencia de justicia..$^{53}$ Pero ni siquiera de esta manera, al menos a nuestro juicio, se puede decir que se avance mucho sobre la determinación del alcance real de la responsabilidad social corporativa y su dimensión ético empresarial. Porque decir que es una herramienta de gestión, en el sentido de que no es una moda, o que no es una especie de limosna que convive con otro tipo de precariedades empresariales, sino que ha de transformar el carácter de la empresa desde dentro, de manera que forme parte de la vida de la empresa transformándola internamente. Y, añadir, que es una medida de prudencia, porque la responsabilidad social debe ayudar a tomar decisiones equilibradas. O en fin, aludir a la exigencia de la justicia, en el sentido de que la ética empresarial exige tomar en consideración a todos los afectados por la actividad empresarial, los denominados stakeholders, porque son interesantes para la supervivencia de la empresa e interesantes por sí mismos. ${ }^{54}$ Con todo esto, puede parecer que se quiere decir mucho, pero en realidad en el mejor de los casos, a nuestro juicio, se trata de un mero

${ }^{49}$ Cfr. Argandoña, A., «Economía de mercado y responsabilidad social corporativa», en Papeles de Economía Española, ı०8, 2006, p. 7 .

${ }^{\circ} \mathrm{Cfr}$. Cortina Orts, A., «La responsabilidad social corporativa y la ética empresarial», en AAVV, Mitos y realidades de la Responsabilidad Social Corporativa en España. Un enfoque multidisciplinar, Cizur Menor, 2006 , p. Iog ss.

${ }^{5 \mathrm{I}}$ Vid. Comte-Sponville, A., El capitalismo, ¿Es moral?, tr. esp., Barcelona, 2004, p. 5I-56. O como también se dice, si las empresas actúan tratando de maximizar el valor y la RSC (que se identifica con la ética) concurre a ese resultado, la RSC no añade nada relevante, salvo que se interprete como un medio (entre otros) para identificar oportunidades de negocio, lo que supone dejar de considerarla como un ejercicio de responsabilidad social (Argandoña, A., «Economía de mercado y responsabilidad social corporativa», en Papeles de Economía Española, Io8, 2006, p. 7-8).

${ }^{2}$ Cfr., con otras referencias, Argandoña, A., «Economía de mercado y responsabilidad social corporativa», en Papeles de Economía Española, I08, 2006, p. 7.

53 En este sentido Cortina Orts, A., «La responsabilidad social corporativa y la ética empresarial», en AAVV, Mitos y realidades de la Responsabilidad Social Corporativa en España. Un enfoque multidisciplinar, Cizur Menor, 2006 , p. II2. Le sigue, entre otros, Tortosa Cosme, E., «Responsabilidad social de la empresa: un nuevo modelo de empresa», en Papeles de Economía Española, ı08, 2006, p. Io6, ss., esp.ıı4-II5.

54 Vid. Cortina Orts, A., «La responsabilidad social corporativa y la ética empresarial», en AAVV, Mitos y realidades de la Responsabilidad Social Corporativa en España. Un enfoque multidisciplinar, Cizur Menor, 2006 , p. II4-II5. 
voluntarismo lleno de buenos deseos, que podemos compartir más o menos todos, pero que en un mercado real difícilmente se podría generalizar a todas las empresas, porque la preocupación fundamental de las empresas es mantenerse en el mercado y para eso necesitan obtener beneficios, o cuando menos unos resultados económicos equilibrados. En este sentido, incluso desde planteamientos nada conservadores, se habla con cierto sarcasmo de las llamadas más o menos sentimentales a una nebulosa «responsabilidad social corporativa», que cada cual interpreta como le apetece, o según las recomendaciones del departamento de relaciones públicas de turno, con sus inspiradas declaraciones morales a favor del buenismo, sobre todo si son otros quienes lo practican. ${ }^{55}$

\section{IV. Ética empresarial y generación de confianza: crisis financiera, exceso de confianza y desconfianza}

Sin perjuicio de lo dicho y de lo que podamos añadir, bien parece que al final todo se reduce en la RSC/RSE a la generación de confianza. ${ }^{56}$ Como si la confianza fuese el nuevo bálsamo curativo de todos los males del mundo de los negocios, cuando en realidad desde siempre ha formado parte del bagaje más apreciado por los comerciantes. ${ }^{57}$ En el celebrado libro de Douglas C. North y Robert Paul Thomas, titulado El nacimiento del mundo occidental. Una nueva historia económica(900-1700), ponen claramente de manifiesto que la clave del crecimiento económico reside en una organización económica eficaz, lo que implica el establecimiento de un marco institucional y de una estructura de derecho de propiedad. ${ }^{5} \mathrm{O}$ más recientemente en el libro de David Landes, La riqueza y la pobreza de las naciones, que alude igualmente a las condiciones institucionales que han de cumplirse para que una sociedad crezca y se desarrolle: los derechos de propiedad, las libertades

55 Vid. Giner, S., El futuro del capitalismo, cit., p. I5-I6.

${ }^{56}$ Cfr. Micklethwait, J./Wooldridge, A., La empresa. Historia de una idea revolucionaria, tr. esp., Barcelona, 2003, p. 2I2-218; Argandoña, A., «Economía de mercado y responsabilidad social corporativa», en Papeles de Economía Española, IO8, 2006, p. 5 y 8; Rodríguez Fernández, JM, «Valor accionarial y orientación stakeholder: bases para un nuevo gobierno corporativo», en Papeles de Economía Española, Io8, 2006, p. Io ss., esp. II; Salas Fumas, V., «Etica y confianza en los mercados financieros», en Papeles de Economía Española, ı०8, 2006, p. 27 ss.; Capron, M./Quairel-Lanoizelée, F., La responsabilité sociale d'entreprise, Paris, 2007, passim, esp. p. 8-9, 20 ss., IIo ss.; Gutiérrez, A., «La gestión del conocimiento», en Alcoberro, R (coor.), Etica, economía y empresa. La dimensión moral de la economía, Barcelona, 2007, p. I4I ss., esp. I55 ss.; Cortina Orts, A., «La responsabilidad social corporativa y la ética empresarial», en AAVV, Mitos y realidades de la Responsabilidad Social Corporativa en España. Un enfoque multidisciplinar, Cizur Menor, 2006, p.ıı6-ır9; García-Marza, D. Etica empresarial: del dialogo a la confianza, Madrid, 2004, passim; R.E. Freeman/K. Martin/B. Parmar, «Stakeholder capitalism», Journal of Business Ethics, 74, 2007, p. 303-3I4. Finalmente, entre los documentos de instituciones públicas nacionales e internacionales, pueden verse los antes mencionados en la introducción del presente trabjo.

${ }^{57}$ Cfr., entre otros, Le Goff, J., Mercaderes y banqueros de la Edad Media, tr. esp., Madrid, 2004, p. IOI-IO3; Pirenne, H., Las ciudades de la edad media, tr. esp., $8^{a}$ reimpresión, Madrid, I989, p. 7I-85; Berman, H.J., La formación de la tradición jurídica de Occidente, tr. esp., México, I996, p. 349-373; Beaud, M., Historia del capitalismo. De I500 a nuestros días, tr. esp., Barcelona, I984, p. 2I-56. Es cierto que, como nos hace ver J. Le Goff, en la época medieval lo propio, no es la confianza, sino la desconfianza con respecto al prójimo, pero esto no desdice de lo que decimos, sino que nos lo confirma, porque refleja la imperiosa necesidad que los comerciantes tienen de la confianza. Así lo pone de relieve Paolo Grossi cuando se refiere a la aparición de un nuevo protagonista medieval: «Y es el mercader ese nuevo protagonista, él también es el signo de confianza y apertura hacia escenarios cada vez más amplio» (Europa y el derecho, tr. esp., Madrid, 2007, p. 40). En definitiva, como dice Amartya Sen (Desarrollo y libertad, tr. esp., Barcelona, 2000, p. 3I6): «El funcionamiento satisfactorio de una economía de intercambio depende de la confianza mutua y del uso de normas explícitas e implícitas. Cuando estos modos de conducta son abundantes, es fácil que pase desapercibido su papel. Pero cuando hay que cultivarlos, esa laguna puede constituir un importante obstáculo para lograr el éxito económico.»

$5^{8}$ Tr. esp., $5^{\text {a }}$ ed., Madrid, I99I[I973], passim. 
individuales, la confianza en las formas contractuales, amén de gobiernos estables y no corruptos que escuchen y atiendan las quejas y los deseos de los ciudadanos. ${ }^{59}$

Muy probablemente, esta confianza del mundo de los negocios, se entronque con la vieja auctoritas romana, en particular con la auctoritas patrum, ${ }^{60} \mathrm{y}$ como es natural con la fides, bona fides:

«La fides, en el mundo romano, es un valor que se perfila individualmente a quien dispone de ella como hombre leal a la palabra dada, fiel a sus compromisos de forma estable y duradera. ....aquel valor es punto de referencia obligado en las relaciones interpersonales. ...La integración de la fides en el Derecho romano se produce desde el mundo de la ética social en los primeros momentos de su Historia. Esta asimilación se opera de forma lenta y progresiva, sin cambios bruscos iniciales,.....En cualquier caso siempre late la misma idea, un solo concepto es respetado en todos los supuestos, y es «la lealtad a la palabra dada», el «fit quod dicitur» ciceroniano. Esta única fides, valor primero del hombre para ser y sentirse persona, que modela relaciones interpersonales, crea ahora, en el mundo jurídico romano, nuevas figuras o transforma aquellas que resultan histórica y socialmente inadecuadas. Ciertas prácticas sociales y comerciales, que por su producción habitual adquieren una solidez considerable, ejercen una influencia decisiva sobre otras prácticas civiles puras bien para reformar éstas o bien para ocupar su lugar dejándolas en desuso.... Esta fides, histórica y actual, siempre una y la misma, evoca «un modelo de conducta», que la conciencia social considera como arquetipo al que han de atenerse las personas para merecer el amparo por el derecho.» ${ }^{61}$

El gran clásico británico de la historia de Roma, E. Gibbon, habla de «la diosa de la fe(de la fe humana y social)»: «A la diosa de la fe(de la fe humana y social) rendían culto los romanos no sólo en sus templos, sino con su vida; y si esa nación era deficiente en las más amables cualidades de la benevolencia y la generosidad, asombraban a los griegos mediante su sincera y sencilla ejecución de los más onerosos compromisos.» ${ }^{62}$ También lo podemos ver en nuestro refranero, como lo recoge el Marqués de Santillana cuando censó el refrán «el buen pagador, heredero es de lo ajeno(el buen pagador es señor de lo ajeno)», que enseña que cuando se pagan las deudas a tiempo, ello sirve de carta de recomendación para obtener nuevos créditos. ${ }^{63}$

Pero no hay necesidad ni de insistir mucho, ni de ir tan lejos, porque la confianza siempre ha estado ligada a la actividad empresarial y a los mercados, lo que sin duda ha influido beneficiosamente donde su intensidad ha sido mayor. ${ }^{64}$ Desde un punto de vista más general, como dice Niklas Luhmann, la confianza reduce la complejidad social yendo más allá de la información disponible y generalizando las expectativas de conducta en que

${ }^{59}$ Landes, D., La riqueza y la pobreza de las naciones, tr. esp., Barcelona, 2000, p. 233 ss. También, cfr. Dahrendorf, R., En busca de un nuevo orden. Una política de la libertad para el siglo XXI, tr. esp., Barcelona, 2005 , p. 23 ss.

${ }^{60}$ Cfr. Domingo, R., Ex Roma Ius, The Global Law Collection, Cizur Menor, 2005, p. 68-99.

${ }^{6 r}$ Castresana, A., Fides, bona fides: un concepto para la creación del derecho, Madrid, I99I, p. 96-I03. Para la Escuela estoica, la buena fe constituye el soporte de la vida en sociedad, como lo recuerda Cicerón (De off. 3.70), y siempre, bona fides est primun mobile ac spiritus vivificantes commercii. Y, además, está en la base del origen del consensualismo contractual, porque éste reposa esencialmente sobre la confianza que se testimonian las partes (Cfr. Rampelberg, R-M, Repères romains pour le droit européen des contrats, Paris, 2005, p. 45 y 63 SS.).

${ }^{62}$ Gibbon, E., Juicio histórico del Derecho romano. Capítulo XLIV de la Historia de la decadencia y caída del Imperio Romano[I788], tr. esp., Madrid-Barcelona, 2006, p. I32.

${ }^{6}$ Cfr., Junceda, L., Diccionario de refranes, dichos y proverbios, Madrid, 2004, p. 85.

${ }^{64}$ Cfr. Fukuyama, F., La confianza (Trust), tr. esp., Barcelona, I998, passim; Revenga, A., «Francis Fukuyama: confianza y progreso en el fin de la historia», en Alcoberro, R. (coor.), Etica, economía y empresa. La dimensión moral de la economía, Barcelona, 2007, p. 53 ss., 
remplaza la información que falta con una seguridad internamente garantizada. De este modo, es dependiente de otros mecanismos de reducción desarrollados paralelamente con ésta, por ejemplo los de la ley, de la organización y, por supuesto, los del lenguaje, aunque no se reduce a ellos. ${ }^{65} \mathrm{Y}$ así lo pone claramente de manifiesto el principio consensualista contractual desde su etapa más temprana en el Derecho romano, que simplifica la conclusión de los contratos al permitir que se sustenten en la confianza que se testimonian las partes, ${ }^{66}$ lo que reduce la importancia de las exigencias formales y da más valor al consentimiento, que pasa a constituirse desde entonces en un poderoso factor de desarrollo de los intercambios económicos. No obstante, es bien cierto que la ruptura con el viejo brocardo romano por el que «de un acuerdo desnudo no nace una acción» ${ }^{67}$ y la aceptación definitiva del consensualismo contractual constituye un proceso histórico muy lento y con una clara influencia del ius canonicum: pacta sunt servanda(el respeto a la palabra dada o los acuerdos deben cumplirse), ${ }^{68}$ que no parece culminar plenamente hasta los siglos XVII y XVIII con las obras de Domat y Pothier. ${ }^{69}$

Más modernamente, la confianza ha estado integrada desde siempre en el moderno Derecho privado por medio del principio de la confianza y de la buena fe, así lo han puesto de relieve desde hace tiempo algunos de los mejores juristas europeos, como son los casos de K. Larenz en su conocido libro Derecho justo(Fundamentos de ética jurídica), ${ }^{70}$ de F. Wieacker, ${ }^{71}$ de Cl-W. Canaris ${ }^{72}$ o de H. Coing, ${ }^{73}$ por citar sólo algunos de los más modernos. Ahora bien, somos plenamente conscientes de que la confianza va más allá de la ley, pero aún así, las estructuras legales favorecedoras o protectoras de la salvaguardia de la confianza mediante un sistema de sanciones, como nos dice de nuevo el propio Niklas Luhmann, producen un efecto generalizador de la confianza..$^{74}$ Adam Smith, al igual que otros pensadores del XVIII, era muy consciente de todo esto y nos habla de la imperiosa necesidad de que un Estado cuente con una ordenada Administración de justicia, que aporte seguridad y confianza al comercio y a las manufacturas:

${ }^{65}$ Confianza, Barcelona, I996, p. I63-164. También, p. 39 Ss., esp. 5I-52.

${ }^{66}$ Vid., no obstante, las observaciones de N. Luhmann (Confianza, cit., p. 58) respecto a la institución legal del contrato: «contiene una reformulación técnica del principio de confianza en términos de ley que se hace demasiado independiente para que la confianza desempeñe un papel ya sea como condición verdadera o como una base para la validez de los convenios.»

67 D. 2.I4.7.I.

${ }^{68}$ Los canonistas de los siglos XII y XIII añadieron a la ciencia jurídica romanista dos cosas: por un lado, el principio de que las promesas son por sí mismas obligatorias por cuestión de conciencia, ya estén «vestidas» o «desnudas». De manera que no se impide ejercer una acción en el caso de un contrato que no esté por escrito o no se haya hecho por juramento, porque un juramento y una promesa sin juramento son iguales a los ojos de Dios, y no cumplir las obligaciones de un pacto equivale a una mentira. Y por otro, a pesar de lo anterior, que no todas las promesas son de cumplimiento obligatorio, sino sólo los acuerdos apoyados en una causa propia, en el sentido de justificada o apropiada, de modo que la moral queda salvaguardada con la exigencia de que el objeto fuese razonable y equitativo, lo que les lleva a plantear la difícil cuestión del pretium iustum (Vid. Berman, H.J., La formación de la tradición jurídica de Occidente, tr. esp., México, I996, p. 259-260).

${ }^{69}$ Cfr. Rampelberg, R-M, Repères romains pour le droit européen des contrats, Paris, 2005, p. 63-69.

70 Traducción y presentación de L. Díez-Picazo, Madrid, I985, esp. p. 90-98.

${ }^{71}$ El principio general de buena fe, tr. esp., con un Prólogo de L. Díez-Picazo, Madrid, I977, esp. p. 49 ss.: la buena fe reenvía a una elemental exigencia personal de ética jurídica, estos es, a la virtud jurídica del mantenimiento de la palabra, a la confianza, a la lealtad.

${ }^{72}$ Die Vertrauenshaftung im deutschen Privatrecht, Munich, I97I, passim; El sistema en la Jurisprudencia, tr. esp., Madrid, I998, p. 57 ss., esp. 6I-67.

${ }^{73}$ Derecho privado europeo, tr. esp., Madrid, I996, I, p. 667-668, II, p. 543-546. Como nos recuerda el autor citado: «Los negocios de los comerciantes se basan en la fides, en la lealtad y la fidelidad y la confianza. Son sustancia y aire vital del comercio.» (Marquard, J., Tractatus politico-juiridicus De jure mercatorum et commerciorum singulari, Francofurti, I662, II, 8, nr. 2,3).

${ }^{74}$ Vid. Luhman, N., Confianza, tr. esp., Barcelona, I996, p. 53 ss., esp. 60 ss. 
«No pueden florecer largo tiempo el comercio y las manufacturas en un Estado que no disponga de una ordenada Administración de justicia; donde el pueblo no se sienta seguro en la posesión de su propiedad; en que no se sostenga y proteja, por obra de la ley, la buena fe de los contratos, y en que no se dé por sentado que la autoridad del Gobierno se esfuerza en promover el pago de los débitos por quienes se encuentran en condiciones de satisfacer sus deudas. En una palabra, el comercio y las manufacturas sólo pueden florecer en un Estado en que exista cierto grado de confianza en la justicia del Gobierno.» ${ }^{75}$

Por otro lado, por si todo esto no fuera poco para desarbolar esa llamada generalizada, recurrente y excesiva que hoy se hace a la confianza como baluarte de la ética empresarial, lo más chocante de todo es que la confianza no se corresponde con el orden moral, sino que constituye un factor psicológico y sociológico vinculado al orden tecnocientífico, esto es, a la propia economía. ${ }^{76} \mathrm{La}$ confianza de la que hablamos está referida más al mercado en su conjunto, que a cada uno de los individuos que participan en él. Y así lo pone de manifiesto el Derecho con su contribución a completar los niveles de confianza necesarios para el buen funcionamiento del mercado. Como tradicionalmente viene sucediendo con la regulación de los derechos de propiedad y otras instituciones jurídico-privadas; en particular el Derecho de contratos, el Derecho de la competencia entendido en sentido amplio, el Derecho de sociedades, el Derecho del mercado de valores y, muy especialmente, el Derecho registral mercantil. En cuanto a la institución registral mercantil -Registro Mercantil-, hay que resaltar su naturaleza intrumental favorecedora de la seguridad jurídica y de la seguridad del tráfico, ${ }^{77}$ en definitiva de la transparencia del mercado, ${ }^{78}$ que es sin duda la mejor forma de conjugar libertad y seguridad. Por eso mismo, en el ámbito del moderno comercio electrónico se demanda una regulación jurídica suficiente, que aporte seguridad y confianza a los consumidores y a todos los posibles usuarios de la sociedad de la información. ${ }^{79}$ Los índices de confianza en los diferentes mercados se mejoran considerablemente con la cobertura de las posibles lagunas jurídicas y con la buena calidad de las leyes, porque es de esta manera como se facilita su conocimiento, su comprensión y su aplicación.

En todo caso, el premio o el castigo que el mercado otorga por la confianza o la desconfianza, respectivamente, no es algo que corresponda a la moral, sino que compete al propio mercado o al Derecho regulador de ese aspecto del mercado. Téngase en cuenta que, como se nos dice: los sujetos que intervienen en el mercado no están en condiciones de juzgar el valor humano de cada comerciante antes de ir de compras, porque si esto fuera necesario ¿qué quedaría del comercio? Las ciencias no son morales ni inmorales, son amorales, no tienen moral..$^{8 \circ}$ Hay que distinguir claramente los diferentes órdenes o planos, de manera

75 Smith, A., Investigación sobre la naturaleza y causas de la riqueza de las naciones[I776], tr. esp., México, FCE, sexta reimpresión, I990, p. 808. La justice of goverment a la que se refiere Adam Smith no es otra cosa que el imperio de la ley (Cfr. Dahrendorf, R., El recomienzo de la historia. De la caída del muro a la guerra de Irak, tr. esp., Buenos Aires, 2006, p. 257-258).

$7^{6}$ Vid. Comte-Sponville, A., El capitalismo, ¿Es moral?, tr. esp., Barcelona, 2004, p. 90.

77 Sobre la importancia de estas dos categorías, y su articulación armoniosa en protección del titular -y no tanto del adquirente- facilitándole la transmisión de su derecho, nos remitimos al clásico opúsculo de Victor Ehrenberg, Seguridad jurídica y seguridad del tráfico, [con especial referencia al Registro Mercantil (1903)], Introducción y traducción de A. Pau, Madrid, 2003, p. 23-II9. Entre nosotros, resulta obligada la referencia a Paz-Ares, C., «Seguridad jurídica y seguridad del tráfico», RDM, I75-I76, I985, p. 7-40.

${ }^{78}$ Sobre esto último, nos remitimos al libro de García-Tuñón, A.M., Gobierno corporativo, información económica y Registro Mercantil, Madrid, 2006, p. 23-28. También, en esta misma obra, el Prólogo de Luís Fernández del Pozo, p. I9-22.

79 Cfr. Castells, M., La galaxia Internet, Madrid, 200I, p. 20; Lessing, L., El código y otras leyes del ciberespacio, tr. esp., Madrid, 200I, passim; Illescas, R. Derecho de la contratación electrónica, Madrid, 200I, p. 33 ss.

${ }^{80}$ Vid. Comte-Sponville, A., El capitalismo, ¿Es moral?, tr. esp., Barcelona, 2004, p. 90. 
que es la ley de la oferta y la demanda la que determina los precios, y no la moral. Y siempre sin perjuicio de las legítimas intervenciones legales. Los deberes morales no gobiernan la economía, ni es bueno que así fuera, sino que es algo que corresponde al mercado(y a la ciencia económica), en tanto que espacio lógico de toma de decisiones económicas, de producción $y$ consumo. Esta es una idea que tienen muy clara incluso quienes no reniegan del todo de la bondad de la ética empresarial, pero aún así no les impide reconocer sus muchas limitaciones. Así lo podemos comprobar en el caso de Gilles Lipovetsky, cuando afirma con toda rotundidad lo siguiente:

«Lo diré una vez más: la misión de la empresa consiste ante todo en crear riqueza, bienes económicos $y$ servicios, $y$ asegurar su competitividad a fin de no ver amenazada su existencia en el futuro. El objetivo de la organización no es hacer el bien moral por doquier y en todo momento. Eso puede constituir una exigencia privada de los individuos, pero no la obligación de una empresa. La solidaridad no puede ser sino una opción instrumental de la misma, una opción ejecutable en la medida en que es compatible con sus intereses económicos, sus perspectivas de desarrollo y el estado del mercado» (La cursiva es nuestra) ${ }^{8 \mathrm{r}}$

Para finalizar este apartado permítasenos una breve reflexión más que pone en cuestión de nuevo esa llamada tan reiterada e insistente a la confianza. ${ }^{82}$ Como vemos resulta una obviedad la necesidad de la confianza para los mercados, siempre ha estado presente desde sus orígenes y no cabe duda de que lo seguirá estando. Pero la cuestión clave a nuestro juicio es ¿cuánta confianza y cuanta desconfianza es necesaria o conveniente en cada caso $y$ en cada mercado ${ }^{8_{3}}$ El incremento de la cuota de confianza en los mercados puede ser beneficioso porque reduce ciertos costes de transacción, sobre todo porque elimina la necesidad de ciertos elementos garantistas, como dice N. Luhmann, reduce la complejidad en un ámbito de libertad personal, ${ }^{84}$ y en buena lógica repercutirá positivamente en el número de negocios y en la generación de riqueza. Pero también hay que valorar que tiene como contrapartida el aumento de los niveles de «riesgo moral» (moral hazard), esto es, las situaciones de exceso de confianza o de abuso de la confianza, que de eso es de lo que se trata cuando hablamos de riesgo moral: cuando un individuo o una empresa acomete acciones muy arriesgadas en la confianza de que si fracasa alguien le sacará del apuro. ${ }^{85} \mathrm{Y}$ es en buena medida en comportamientos de este tipo donde radica en parte la causa de la crisis financiera de los últimos años. Especialmente por lo que se refiere a algunos de los grandes bancos internacionales(pero también de entidades financieras no tan grandes y de ámbito nacional), que fueron asumiendo grandes riesgos en la

\footnotetext{
${ }^{8 \mathrm{I}}$ Metamorfosis de la cultura liberal. Etica, medios de comunicación, empresa, tr. esp., Barcelona, 2003, p. 86-87. También, en términos no muy distintos, Giner, S. (El futuro del capitalismo, cit., p. II6): La solidaridad económica como guía práctica de gerencia empresarial conduce directamente a la suspensión de pagos y a la bancarrota. La empresa debe ser, ante todo, un buen negocio: pagar a sus asalariados, reinvertir capital, cumplir con los impuestos, competir eficazmente en el mercado y repartir entre sus amos el sobrante en forma de beneficio.

${ }^{82}$ Cfr. Olcese Santonja, A., El capitalismo humanista, cit., p. 7I, que habla de que la confianza se ha deteriorado por un exceso de control sobre el comportamiento de la personas porque no son dignas de confianza, de donde deduce la necesidad de reducir el énfasis en el control en beneficio del fomento de la confianza.

${ }^{83}$ A este respecto resulta fundamental la aproximación al capítulo final del citado libro de N. Luhmann: Confianza, cit., p. I49-I64 (Capítulo XII: La racionalidad de la confianza y la desconfianza): "Que la confianza sea racional, correcta y dirigida moralmente era un asunto que en realidad se formulaba en la filosofía moral pero incapaz de ser resuelto...Obviamente hay algunos casos que requieren confianza y otros que requieren desconfianza. Esto es racionalmente irrefutable. Por lo tanto, se desprende que la confianza no puede ser una máxima para la conducta que es válidad sin excepción.....aun si hay una regla general formulada acerca de la confianza, como un principio, la decisión en cuanto a si debería seguirse o no debe delegarse y dejarse a la situación» (p. I49).

${ }^{8}$ Ibid. p. 5 I.

${ }^{85}$ Vid. Tortella/Núñez, Para comprender la crisis, Madrid, 2009, p. Iı8.
} 
confianza(justificada, pero ciertamente de manera excesiva) de que el Estado las rescataría si las cosas venían mal dadas para evitar el daño que causaría su quiebra. Se trata sobretodo del temido riesgo sistémico, de «demasiado grande para caer» (too big to fail), ${ }^{86}$ que como se nos dice sintetiza ese peligro fatal del exceso de confianza. ${ }^{87}$ Con esto lo que queremos poner de manifiesto es que la confianza es necesaria, pero en su justa medida, porque los peligros también vienen por un exceso de la misma. El riesgo es algo connatural a la actividad empresarial, pero es tanto de buen empresario asumirlo como controlarlo, porque la confianza depende de que la inclinación al riesgo se mantenga bajo control y de que la cuota de desilusiones no sea demasiado grande. ${ }^{88}$ De ahí que en los tiempos que corren, o en situaciones menos malas, las llamadas a la confianza deban ser siempre ponderadas. Es más, en buena lógica y por mucho que nos pese, cuando los peligros de impago acechan lo que prima es la desconfianza. Y no está mal del todo que sea así, porque en un sistema de alta complejidad, que necesita más confianza, también necesita al mismo tiempo de más desconfianza $y$, por lo tanto, debe institucionalizar la desconfianza, por ejemplo en la forma de supervisión. ${ }^{89}$ Buena prueba de lo que se dice la encontramos en importantes disposiciones legales recientes que han ido apareciendo con la crisis económica. A título de ejemplo nos referimos a la reciente Ley 2/20II, de Economía Sostenible, donde la recuperación de la confianza pasa necesariamente por una llamada de atención a las entidades de crédito para que, sobre la base de una información suficiente, evalúen(deberán) la solvencia del potencial prestatario. ${ }^{90}$ Se trata sin duda de un mandato legal que podemos considerar hoy día justificado, pero en cualquier caso sorprendente y un tanto sospechoso, porque resulta una obviedad para la actividad empresarial en general, y especialmente para la financiera, la necesidad de verificar la solvencia de sus potenciales clientes. No obstante, a nuestro juicio, la norma incide sobre este aspecto para recordar lo que de siempre ha constituido una buena práctica bancaria y acabar con ciertas alegrías crediticias que han sido producto, en el mejor de los casos, de un exceso de confianza. En definitiva podemos concluir diciendo que la confianza se ha debilitado, porque se ha abusado de la misma, y ha dado paso a una etapa de desconfianza, de modo que su recuperación sólo será posible con calma y con cierta ayuda institucional. ${ }^{\text {I }}$ De ahí que las llamadas exasperadas y desesperadas a la rápida recuperación de la confianza por los mercados sólo contribuyan a generar más desasosiego, esto es, más desconfianza.

\section{La moral no es un buen instrumento para gobernar la empresa: los peligros de la autorregulación}

Hay que partir de la idea de que la moral que pueda aparecer en el desarrollo de la actividad empresarial no surgirá autogenerada por el propio mercado, no debe ser así, y cuando se ha pretendido el fracaso ha sido mayúsculo, como ha sucedido con el socialismo marxista-colectivista, sino que deberá proceder del exterior..$^{92}$ La moral, una vez que llega al

\footnotetext{
${ }^{86}$ Vid. Stiglitz, J.E., Caída libre. El libre mercado y el hundimiento de la economía mundial, tr. esp., Madrid, 2010, p. 209-213.

${ }^{87}$ Vid. Tortella/Núñez, Para comprender la crisis, cit., p. Iı8.

${ }^{88}$ Vid. N. Luhmann, Confianza, cit., p. I55.

${ }^{89}$ Lo tomamos de N. Luhmann, Confianza, cit., p. I55.

${ }^{\circ}$ Nos referimos al artículo 29 de la LES («Responsabilidad en el crédito y protección de los usuarios de servicios financieros»). También lo podemos ver en el artículo 8 de la Directiva 2008/48/CE, relativa a los contratos de crédito al consumo.

${ }^{9}$ Cfr. Stiglitz, J.E., Caída libre, cit., p. 336.

${ }^{92}$ En este sentido Comte-Sponville, A., El capitalismo, ¿Es moral?, tr. esp., Barcelona, 2004, p. 93-96. También puede verse, Peces-Barba, G., Etica pública y Derecho, Real Academia de Ciencias Morales y Políticas, Discurso de recepción, Madrid, I993, p. 29.
} 
poder, amenaza con corromperse. ${ }^{93} \mathrm{Y}$ no es que la moral sea algo que se encuentre indefenso, porque tiene un gran potencial de poder respecto a ciertas cosas, como son respecto a la integridad de una persona y el respeto propio y ajeno, como respecto a nuestra visión del mundo y la dirección de nuestros impulsos, crea expectativas, modifica el derecho, trasciende los límites de las culturas; pero en su actualización, esto es, en su paso de lo abstracto a lo concreto, entre el poder y la impotencia, expuesta además al abuso y a la ilusión, el poder de la moral será siempre precario. ${ }^{94}$

El mercado funciona sobre la base de un juego de intereses, de intercambio de prestaciones, que derivan en comportamientos no necesariamente generosos o caritativos, aunque sí pueden ser calificados de solidarios; mientras que la moral constituye un catálogo de deberes personales que no entran en juego por interés, sino de manera desinteresada, por tanto al margen del mercado. Ahora bien, esto no impide, que cualquier empresario o directivo pueda tomar decisiones amparado o empujado por sus convicciones morales, sin duda que lo pueden hacer. Decisiones tales como no despedir, cuando deberían hacerlo bien por razones internas o externas a la empresa; o bien gastar más de lo exigido por la ley en la protección del medio ambiente; o comprar mercancías a un proveedor inadecuado para ayudarle a salir de su crisis empresarial; o vender sus productos a una ONG por debajo del precio de coste o ligeramente por encima; 95 o no deslocalizar a tiempo una empresa para salvarla o mejorar su nivel de competitividad; ${ }^{6}$ o en fin, contratar como empleados a personas necesitadas pero a todas luces incompetentes o inadecuadas para la realización de las labores a las que están destinados; o contratar más personal del necesario, etc. Y así podríamos seguir en una larga lista casi interminable de lo que la lógica del mercado desaconseja, por mucho que la moral individual pondere este tipo de decisiones. No obstante, no se puede negar que en ciertos casos, las empresas que adoptan alguno de estos comportamientos pueden obtener algún tipo de beneficio, como puede ser evitar la posible publicidad negativa, o bien conseguir una mayor calidad de la mano de obra que atraen, seducida como es natural por el marchamo de empresa socialmente responsable. ${ }^{97}$ Pero no son aspectos fundamentales del gobierno de la empresa. Se trata de meros aspectos de buena imagen empresarial, que sin duda no se deben descuidar, pero que no se deben sobrevalorar. Es más, desde hace bastante tiempo, casi desde principios del siglo XX, nos consta que las empresas han venido cuidando su imagen corporativa, porque no sólo venden productos o servicios, sino que también se venden a sí mismas, porque todo forma parte del negocio..$^{98}$

Pero sea como sea, lo verdaderamente importante, y sobre lo que queremos insistir, es que los directivos de una empresa que se precie no deben regirse como regla general por este tipo de comportamientos caritativos o «solidarios», porque los días de la

${ }^{93}$ Se trata de una idea kantiana que tomamos de Höffe, O. («Sobre el poder de la moral», en El proyecto político de la modernidad, tr. esp., Buenos aires, 2008, p. I05 Ss., esp. I26) y que figura en Hacia la paz perpetua: «la posesión del poder echa a perder inevitablemente el libre juicio de la razón».

${ }^{94}$ En este sentido Höffe, O., «Sobre el poder de la moral», cit., p. I26.

${ }^{5}$ Aquí la cuestión es delicada, porque se podría estar infringiendo el art. I7 de la Ley de competencia desleal (Cfr. Massaguer, J., Comentario a la LCD, Madrid, I999, p. 495 Ss.).

${ }^{96}$ La cuestión de la deslocalización de empresas es una de las cuestiones más discutidas en los últimos años en el ámbito económico-social, pero hay que tener presente que constituye una de las facetas propias de la libertad de empresa (art. 38 de la CE), la libertad de salida del mercado, junto con la libertad de entrada y la libertad de determinación de la conducta competitiva (Vid., especialmente, Rojo, A., «Actividad económica pública y actividad económica privada en la Constitución española», RDM, I983, p. 327 ss.). El Tribunal Constitucional ha dado carta de naturaleza a esta faceta de la libertad de empresa en varias sentencias (SSTC, 64/I990 y 135/I992), cuando habla de la libertad de traslado de las industrias dentro del territorio estatal como manifestación relevante de la libertad de empresa, como libertad de elección por la empresa de su propio mercado.

${ }^{97}$ Cfr. Stiglitz, J.E., Cómo hacer que funcione la globalización, tr. esp., Madrid, 2006, p. 255.

$9^{8}$ Vid. Bernays, E., Propaganda[I927], tr. esp., Barcelona, 2008, p. 79-87. 
empresa estarían contados, se estarían tirando piedras contra su propio tejado. La pregunta inmediata sería la siguiente: ¿cómo se puede hablar en estos casos de empresas sostenibles, entendidas como empresas de presente y de futuro?, ${ }^{99}$ cuando cabe la posibilidad de que tales decisiones empresariales las aboquen a su desaparición. En el sistema económico capitalista hay que aceptar que los individuos y las empresas actuarán guiadas por su propio beneficio, más que persiguiendo fines sociales deseables, que deberán ser alcanzados por otros medios. Especialmente, cuando se trate de los objetivos sociales más amplios, que se deberán buscar por medio de las leyes, los impuestos y la consiguiente redistribución de la riqueza, pero no por la pretensión falaz de que las empresas decidan en algún momento pagar salarios «justos»o preocuparse más por el medioambiente. ${ }^{\mathrm{IOO}}$ Luego en definitiva, en buena lógica, no es muy probable que los empresarios o sus directivos actúen de este modo voluntaria y generalizadamente, porque se trataría de comportamientos sino suicidas sí contraproducentes desde el punto de vista empresarial.

Y si lo anterior es correcto, si la lógica del mercado nos dice que la ética o la moral no deben gobernar la empresa, sino que debe regirse, por supuesto siempre con fidelidad a la ley, por los principios y directrices propios de la ciencia económico-empresarial, uno no acierta a entender cómo es posible que en los momentos actuales se hable tanto, y por tantos, de las bondades de la ética empresarial(versión empresarial del retorno de la moral), o de lo que es lo mismo de la RSC/RSE, para resolver los males que presuntamente acechan a las empresas o al entero sistema capitalista. ${ }^{\text {Io }}$ Puede parecer que lo que se pretende es transformar los problemas económicos(orden técnico-científico) y, especialmente, los político-jurídicos en «simples» cuestiones morales. Cuando en realidad no hace falta dar muchas vueltas a la cabeza para entender que la moral no puede resolver ni los unos ni los otros. Sobre los primeros no hay que insistir mucho, porque la cuestión es meridiana. Como es sabido desde el Mercantilismo se produce la ruptura intelectual entre lo económico y lo moral, ${ }^{102}$ hasta el punto de que se puede decir que los mercantilistas eran amorales en un doble sentido, en cuanto a los fines y en cuanto a los medios para alcanzarlos. El foco de atención pasa del individuo a la sociedad, al bien del Estado(raison d'etat o puro maquiavelismo) y donde se manifiesta especialmente es en el tratamiento de la usura(también respecto al lujo), donde aparecen nuevos motivos de naturaleza económica que desplazan a las motivaciones de carácter moral. ${ }^{\mathrm{I} 3}$ Ahora bien sobre los segundos, los problemas político-jurídicos, sí que hay que insistir, porque puede existir -de hecho existecierta inclinación a pensar que, efectivamente, la moral puede sustituir al Derecho y a la Política. Nada más lejos de la realidad, se trata de un error tremendo en el que no debemos

${ }^{99}$ Cfr. Rodríguez, M.A., en Real Academia de Ciencias Económicas y Financieras, dir. Aldo Olcese Santonja, La Responsabilidad Social de la Empresa (RSE). Propuesta para una nueva economía de la empresa responsable y sostenible, Madrid, junio 2007, p. IO2 ss. (www racef.es). También, Olcese Santonja, A., El capitalismo humanista, Madrid, 2009, p. 42.

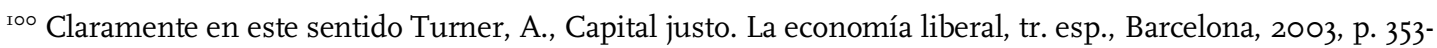
354 .

${ }^{\text {Ior } C f r . ~ O l c e s e ~ S a n t o n j a, ~ A ., ~ e n ~ R e a l ~ A c a d e m i a ~ d e ~ C i e n c i a s ~ E c o n o ́ m i c a s ~ y ~ F i n a n c i e r a s, ~ d i r . ~ A . ~ O l c e s e ~ S a n t o n j a, ~}$ La Responsabilidad Social de la Empresa (RSE). Propuesta para una nueva economía de la empresa responsable y sostenible, Madrid, junio 2007, p. 35 ss., esp. 45 Ss. (www racef.es). Más recientemente, del mismo autor, El capitalismo humanista, cit., p. 40, 42 y 58.

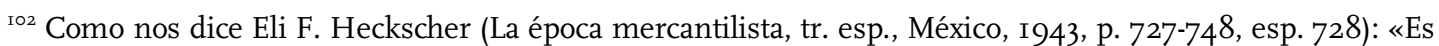
cierto que los canonistas había intentado, con ingenio y habilidad, dar a la prohibición de cobrar intereses una forma tal que no chocase más de lo necesario con los hechos económicos, de los cuales no era posible prescindir. Pero esto se hacia sin abandonar, en principio, el carácter absoluto de la prohibición, pues ésta descansaba, para los canonistas, en un precepto religioso que las consideraciones seculares no podían modificar. La novedad consistía en hacer desaparecer esta base sobre [la] que descansaba la prohibición. De momento, lo que cambiaba era más bien la motivación que las consecuencias prácticas que de ella se desprendían. Con el tiempo, fueron cambiando también, poco a poco, las consecuencias.»

I03 Ibid. p. 729-733. 
caer, porque nos estaríamos engañando a nosotros mismos y es la mejor manera de no resolver nunca ni los problemas económicos ni los político-jurídicos. ${ }^{104}$

La única explicación posible, o al menos la más plausible a nuestro juicio, es que con esta avalancha en los últimos años de ética empresarial, o si se quiere de RSC/RSE, se pretende fundamentalmente dos cosas. Por un lado, mejorar la imagen pública de las empresas, especialmente de las grandes corporaciones, que como es sabido dicha imagen se ha visto deteriorada últimamente a consecuencia de los grandes escándalos protagonizados especialmente por empresas norteamericanas(Enron, Arthur Andersen, WorldCom, Adelphia, Global Crossing, Tyco, etc.), ${ }^{105}$ aunque no sólo de este país(caso Parmalat en Italia). Se habla en estos casos de la responsabilidad social como un instrumento para el fomento de la reputación empresarial. Y por otro, y esto nos parece mucho más preocupante, la RSC/RSE guarda en sí misma un alto componente autoregulatorio, ${ }^{106}$ dado su carácter voluntario, que por lo general responde a intereses corporativos. En este caso, los Códigos éticos o las guías de buenas prácticas, sin perjuicio de una cierta utilidad, tienen por finalidad primordial la de evitar la aprobación de disposiciones legales más severas; o en todo caso, preservar el monopolio profesional que siempre será más flexible que una reglamentación jurídica. ${ }^{107}$ Así se ha hecho ver desde planteamientos nada sospechosos como es el caso del comunitarismo:

«[T]odas las sociedades basadas en la Tercera Vía deben ser más claras sobre las áreas en las que las fuerzas del mercado no pueden introducirse. Esto es esencial para preservar y desarrollar el necesario equilibrio entre el reino de lo instrumental y el de los fines... Los mercados no pueden quedar liberados del control público y de la regulación. Se puede confiar, hasta cierto punto, en la autorregulación del mercado, por ejemplo, a través de un acuerdo por el que las empresas se comprometan a no influir con su publicidad en el comportamiento de los niños más pequeños. Y las comunidades pueden desempeñar el papel de garantes de que eso se cumpla. Por ejemplo, muchas asociaciones de consumidores juegan un importante papel como guardianes informales del comportamiento de las empresas. Pero la experiencia demuestra que la última responsabilidad efectiva para evitar los excesos del mercado debe recaer en el estado. Con el fin de asegurar que la regulación del mismo no sea excesiva, las normas estatales se aplicarán solamente si queda demostrado que no resultan innecesariamente restrictivas con el mercado o que no pueden sustituirse por regulaciones mejores o por otros modos de conseguir los mismos propósitos sociales.»108

Pero hay aquí un problema añadido, con un ámbito mucho más general, como es el de la crisis de la ley o de las transformaciones de la misma, que ha dado lugar al desarrollo -especialmente por influencia anglosajona- del para-derecho o en terminología

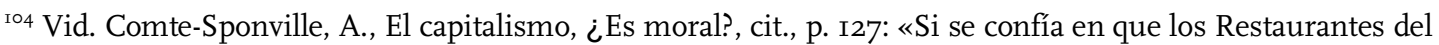
Corazón venzan la miseria y la marginación, si se confía en que el humanitarismo sustituya a la política exterior, en que el antirracismo reemplace a la política de inmigración, es que uno se engaña a sí mismo».

${ }^{105}$ Cfr. Bogle, J.C., La batalla por el alma del capitalismo, tr. esp., Madrid-Barcelona, 2007, p. 47-93; Stiglitz, J.E., Los felices 9o. La semilla de la destrucción, tr. esp., Madrid, 2003, p. 287 ss.; Galbraith, J.K., La economía del fraude inocente. La verdad de nuestro tiempo, tr. esp., Madrid, 2004, p. $83-87$.

${ }^{106}$ Cfr. Olcese Santonja, A., El capitalismo humanista, cit., p. 27, esp. I65 ss.

${ }^{107}$ Cfr. Monnier, S. Les Comités d'ethique et le droits. Eléments d'analyse sur le systéme normativif de la bioéthique, Paris, 2005, p. 9I-93; Cabanillas Sánchez, A./Zavala, J., «El principalismo y su influencia en la normativa española sobre investigación biomédica», en Libro Homenaje a Gregorio Peces-Barba, v. I, p. 227 Ss., Madrid, 2008.

${ }^{108}$ Etzioni, A., La tercera Vía hacia una buena sociedad. Propuestas desde el comunitarismo, tr. esp., Madrid, 200I, p. 8I (la cursiva es nuestra). 
inglesa Soft Law, con una directa conexión con la temática de la globalización. ${ }^{\text {109 }}$ Desde un punto de vista todavía más general esta problemática se puede enmarcar dentro de la crisis del Estado de derecho, ${ }^{\text {IIO }}$ o si se quiere dentro de la más moderna crisis del Estado constitucional. ${ }^{\text {III }}$ Como es natural no podemos entrar en grandes profundidades sobre estas problemáticas, que nos superan en mucho, sólo nos permitimos este pequeño apunte y recogemos aquí algunos fragmentos de lo que se ha dicho por una de las voces más autorizadas del pensamiento europeo, como es el caso del prof. J. Habermas: ${ }^{\text {:I2 }}$

Por un lado, nos dice:

«El aumento de las tareas de regulación-control no sólo tiene por consecuencia la autonomización del aparato administrativo frente a un legislador marginalizado. Envuelve también al Estado en negociaciones con los sistemas funcionales de la sociedad, con las grandes organizaciones, con las grandes asociaciones, etc., que cada vez se sustraen más a una regulación imperativa(a través de sanciones, impuestos o estímulos financieros) y sólo resultan ya accesibles a medios persuasivos de comunicación: «Frente a la regulacióncontrol de tipo indirecto no se da ningún deber de obediencia...Las medidas políticas se convierten en objeto de negociaciones, en las que los destinatarios privados de esas medidas de control del Estado se hacen pagar por el Estado su(de ellos) disponibilidad a la obediencia...Estado y sociedad están aquí frente a frente en un mismo plano». La soberanía del Estado queda enterrada en la medida en que corporaciones socialmente poderosas participan en el ejercicio del poder público, sin quedar sujetas a las responsabilidades que son habituales cuando se trata de órganos del Estado.»

\section{Por otro,}

[N]o puede aceptarse sin más «la conclusión de que la complejidad de las nuevas tareas de regulación y control de que ha de hacerse cargo el Estado desbordan como tal el medio que es el derecho.....La fuerza sociointegradora del derecho sólo habría quedado estructuralmente desbordada si la crisis del Estado de derecho se presentase como una crisis sin salida. Sospecho que tal sensación de hallarse en una situación de salida se debe más bien a los prejuicios funcionalistas de esa comprensión del derecho que no logra apartar la vista de la actividad estatal.» De manera que los «signos de erosión del Estado de derecho señalizan, ciertamente, tendencias de crisis; sin embargo, lo que en ellos se manifiesta es más bien una insuficiente institucionalización de los principios del Estado de derecho que una sobrecarga que, sin posibilidad alguna de salida, esos principios hubiesen impuesto a una actividad estatal que se vuelve cada día más compleja.»

\section{Y termina diciéndonos:}

«[L]a arquitectónica del Estado de derecho sufre quebranto cuando el Estado se contenta en tales negociaciones con la posición de un participante entre otros. Ante decisiones políticas que resultan relevantes para la sociedad global, el Estado tiene que seguir haciendo valer los intereses públicos y, llegado el caso, tiene que poder imponerlos. Aun cuando en tales casos, el Estado se presente en el papel de un consejero o de un supervisor inteligente que pone derecho procedimental a disposición de quien lo haya menester, la producción normativa que se siga de ello ha de quedar retroalimentativamente

\footnotetext{
Io9 Una aproximación a estas cuestiones puede hacerse en el libro del profesor Laporta, F.J., El imperio de la ley. Una visión actual, Madrid, 2007, p. 243-265, donde se ocupa de la relación entre el Imperio de la ley y la globalización.

${ }^{\text {II }}$ Cfr. Habermas, J., Facticidad y validez. Sobre el derecho y el Estado democrático de derecho en términos de teoría del discurso, tr. esp., Madrid, I998, p. 512-532.

${ }^{\text {III }} \mathrm{Al}$ respecto para una primera aproximación nos remitimos a García, E., El Estado constitucional ante su «Momento Maquiavélico», Madrid, 2000, esp. p. 55 ss.

${ }^{\text {II2 }}$ Habermas, J., Facticidad y validez, cit., p. 519, 520, 522, 527-528 y 530, respectivamente.
} 
conectada de forma transparente, inteligente y controlable con los programas del legislador. Y para ello no hay recetas patentadas. Contra la autonomización del poder ilegítimo, en última instancia sólo cabe recurrir a su vez como «paladión de la libertad» a un espacio público informado, despierto, móvil, desconfiado, que influya sobre el complejo parlamentario e insista en hacer que se cumplan las condiciones de nacimiento del derecho legítimo.....El sustrato social para la realización del sistema de los derechos no lo constituye ni las fuerzas de una sociedad de mercado que opere de forma espontánea, ni tampoco las medidas de un Estado social que opere de forma intencional, sino las corrientes de comunicación y los influjos de tipo publicístico que surgen de la sociedad civil y del espacio público-político y que a través de procedimientos democráticos se transforman en poder comunicativo.» Y finalmente: «..el Estado ha perdido su sustancia sacra. Esta secularización de las bases espirituales del poder del Estado, que se puso en marcha hace ya mucho tiempo, padece de un ya moroso déficit de ejecución, que ha de ser compensado mediante un paso adelante en el proceso de democratización si queremos evitar que el propio Estado de derecho se vea en peligro....Quien se opone a las perspectivas reformistas con los habituales argumentos relativos a complejidad, confunde la legitimidad con la eficacia y desconoce que las instituciones del Estado de derecho tuvieron desde siempre la finalidad, no sólo de reducir la complejidad, sino también de mantenerla mediante contrarregulación, con el fin de estabilizar la tensión entre facticidad y validez, que es inherente al derecho.»

Nos gustaría tener la capacidad de síntesis para resumir en un par de frases la riqueza de contenidos que podemos ver en el texto del prof. Habermas. Pero la verdad es que nada mejor que sus propias palabras para expresar lo que queremos decir. No obstante, a nuestro juicio, la idea central la constituye su llamada de atención sobre el enorme peligro de deslegitimación del Estado democrático respecto a la producción del Derecho. Y la verdad es que algo de todo esto que nos dice Habermas se ha puesto de manifiesto con la crisis económica más reciente de la deuda pública en Europa, como lo atestiguan las recientes declaraciones del profesor Joseph Stiglitz: «Un Banco Central Europeo que, como en el caso griego, delega su responsabilidad a un grupo secreto de especuladores en Nueva York, la ISDA(Asociación Internacional de Swaps y Derivados), es irresponsable. Los gobiernos delegan en tecnócratas y ellos lo hacen en inversores privados y eso está socavando la democracia. La crisis prueba que un grupo determinado de tecnócratas se han equivocado gravemente y ¿qué hacemos? Los ponemos al frente de la economía.» ${ }^{\mathrm{II} 3}$

\section{La ética empresarial como fuente de confusión}

A la vista de lo anterior, y por lo que se refiere a las actos desvinculados de la actividad empresarial, ${ }^{\mathrm{II} 4}$ nos parece de lo más sensato mantener o continuar con la práctica

\footnotetext{
זॅ3 Vid. Diario El Mundo, Domingo 27 de noviembre de 20II, Mercados, p. Iо.

${ }^{\text {II4 }}$ Nos referimos aquí a actividades dirigidas a la comunidad en general, culturales, de beneficencia, de protección del medio ambiente, etc. En cuanto a los otros, los vinculados a la actividad empresarial, están directamente relacionados con el interés social de las empresas societarias. Se trata de otro aspecto importante, pero polémico, de la RSC/RSE al que nos referiremos más adelante. La cuestión, en el fondo, a nuestro juicio, es muy similar y debe ser canalizada, no por medio de la moral o la ética de la empresa, sino por medio del contrato y la ley. Ya se trate de contratos individuales, negociación colectiva o de cualquier otro tipo de acuerdo entre las empresas y los denominados stakeholders. Aunque esta expresión anglosajona puede convertirse en un cajón de sastre donde quepa todo tipo de sujetos y relaciones con la empresa, nosotros la entendemos preferentemente referida a los trabajadores de la empresa, clientes, consumidores, proveedores, acreedores financieros y comerciales. Dejamos por tanto fuera a la comunidad en general, que es la destinataria de las actos desvinculados de la actividad empresarial, y a los accionistas, que son los shareholders (Cfr., Alonso Ledesma, C., voz «Stakeholders», en Diccionario de Derecho de Sociedades, dir. Alonso Ledesma, C., Madrid, 2006, p. I249-I250; Martínez, J.L./Carbonell, M./Agüero, A., Los stakeholders..., cit., passim; Embid Irujo, JM, «La responsabilidad social..,» cit., p. II ss., esp. I5-2I y 36 ss.; idem, «Derecho, mercado y responsabilidad social corporativa», cit., p. 63-74; Esteban Velasco «Interés social, buen gobierno y responsabilidad social
} 
tradicional del mecenazgo a través de la creación de fundaciones anejas o vinculadas a las grandes corporaciones empresariales. O también, si se quiere, la promoción o colaboración con ONGs, porque es de esta manera -aunque no hay que olvidar los previsibles beneficios fiscales- como se facilita la distinción de planos, y porque se discrimina claramente los recursos vinculados a fines no empresariales y su concreto destino, ya sea cultural, de beneficencia o de cualquier otro tipo de filantropía. Sin perjuicio de que no se puede negar de entrada la posibilidad de algunas fórmulas de integración más o menos exitosas, pero obsérvese que en ningún caso se pierde de vista el criterio de la rentabilidad. ${ }^{\text {II }}$

No obstante, una salvedad importante, al menos desde el punto de vista teórico, nos viene dada por el propio Derecho de sociedades y el principio de autonomía privada, en este caso autonomía estatutaria. Existe la posibilidad de que las sociedades mercantiles, con la más que probable excepción de las sociedades cotizadas, puedan constituirse con una finalidad no lucrativa o con un fin de lucro limitado, lo que sin duda puede resultar un tanto extravagante, pero que a nuestro juicio la ley lo permite. En estos casos, la sociedad podría destinar sus beneficios(lucro objetivo) a cualquier tipo de obras sociales o a otras finalidades distintas al reparto de dividendos a los socios, que es lo que verdaderamente constituye el lucro en sentido estricto según los códigos decimonónicos(lucro subjetivo). Pero obsérvese que incluso careciendo del lucro subjetivo(fin de reparto a los socios) no desaparecería el lucro objetivo, que es el que verdaderamente le sigue imponiendo competir en el mercado y obtener beneficios, porque de no ser así no podría cumplir con su pretendida finalidad social. ${ }^{\mathrm{II} 6}$ La cuestión resulta mucho más clara, si nos fijamos en el caso de las fundaciones, en particular en las Cajas de Ahorros, al menos hasta fechas recientes, pues si bien participan en el sector financiero con una clara finalidad empresarial de búsqueda de beneficios(lucro objetivo), tienen vedado por ley el reparto de los mismos, esto es, carecen de un lucro subjetivo. Sus beneficios tienen que ser destinados bien a reservas(al menos el 50\%) o bien a obras sociales. Y en una situación de crisis como la presente nos anuncian que «congelan» su aportación a la obra social. ${ }^{\text {II7 }}$

En todo caso, a nuestro juicio, mezclar sin más en una misma entidad, por lo general una sociedad de capitales cotizada en bolsa, la legítima finalidad lucrativa con otro tipo de finalidades, con el grado de intensidad que aparenta la RSC/RSE, no puede dar lugar más que a generar confusión. ${ }^{\mathrm{II}}$ Como dice J.K. Galbraith:

«La libertad para la acción económica benéfica es necesaria; esta libertad, sin embargo, no tiene por qué ser una tapadera para la malversación, legal o ilegal, de renta o riqueza ajenas. La dirección corporativa debe tener autoridad para actuar, pero no para el robo aparentemente inocente. Controlar el poder corporativo es uno de nuestros mayores retos y, dadas sus dimensiones, una de nuestras necesidades más urgentes..» ${ }^{\text {II }}$

corporativa...», cit., p. I3 ss., esp. 25 ss. Y 3 I ss.; Sánchez-Calero Guilarte, J., voz «Responsabilidad social corporativa», cit., p. IO23 SS., esp. I029-IO3I).

II Así sucede recientemente con la empresa española Inditex, que ha puesto en marcha un sistema de franquicia, vinculado a una fundación, para desarrollar políticas empresariales propias de la responsabilidad social corporativa, pero bien entendido que se trata de proyectos con cierta singularidad y que buscan siempre la rentabilidad (Vid. Diario El Mundo, suplemento Mercados, domingo 7 de septiembre de 2008, p. I7).

${ }^{\text {II6 }}$ Ahora bien, hay que decir que esta posibilidad estatutaria de la finalidad no lucrativa de las sociedades mercantiles, que asumimos, sigue siendo un tanto controvertida en la doctrina (Cfr., entre otros, Girón Tena, J., Derecho de sociedades, I, Madrid, I976, p. 3I-39; Paz-Ares, C., en Uría-Menéndez, Curso de Derecho Mercantil, I, $2^{a}$ ed., Cizur Menor, 2006, p. 47I-475).

${ }^{\text {II7 }}$ Cfr. Diario El Mundo, miércoles io de septiembre de 2008, p. 34.

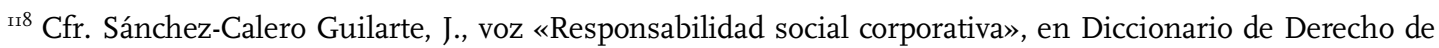
Sociedades (dir. Alonso Ledesma, C.), Madrid, 2006, p. I023 ss., esp. I025-IO27. 87.

${ }^{\text {II }}$ Galbraith, J.K., La economía del fraude inocente. La verdad de nuestro tiempo, tr. esp., Madrid, 2004, p. 
La confusión puede afectar a todos los frentes, a los consumidores, a los inversores, a los acreedores y a los administradores sociales. A los consumidores(i), porque pueden verse seducidos por los cantos de sirena del nuevo logo, como es el de la «empresa socialmente responsable». ${ }^{120}$ Hay que recordar aquí los peligros que puede presentar la denominada publicidad institucional, especialmente en estos casos, cuando la empresa se presenta bajo una aureola de moralidad que no necesariamente tendrá que guardar relación con las bondades de sus productos o servicios. O también las acciones empresariales a largo plazo, claramente interesadas, realizadas con cargo a beneficios a corto, pero que parecen al servicio de objetivos más amplios de la compañía o de los accionistas. ${ }^{21}$ Confusión para los inversores(ii), presentes y futuros, porque no sabrán muy bien a qué atenerse, dado el alto grado de indeterminación que comporta el concepto de RSC/RSE. Por ejemplo respecto a $i$ qué parte de los recursos se destinarán a esta finalidad?, o sí ¿repercutirá dicha finalidad en la política de dividendos?, o en fin, ¿cómo se podrá documentar de manera fiable esta información no financiera? Es cierto que al albur de esta moda están apareciendo, a su vez, métodos de medición y empresas o entidades especializadas en llevarlos a efecto o auditar el grado de responsabilidad social con el que se actúa en el mercado, ${ }^{122}$ pero difícilmente podemos dar una alta fiabilidad a estos índices de medición. En primer lugar, y fundamentalmente, por la razón antes apuntada de la indeterminación conceptual de la propia RSC/RSE y, segundo, porque desconocemos ante qué tipo de empresas estamos, en todo caso carentes de una regulación mínima que nos garantice, al menos, que no se presentan conflictos de intereses con las auditadas. Los malos vientos de los últimos tiempos sobre el sector tradicional de las auditorias, ${ }^{\mathrm{I} 23}$ y más recientemente de las agencias de calificación de riesgos(rating), ${ }^{124}$ nos aconsejan ser muy cautelosos sobre cualquier tipo de medición en la empresa. ${ }^{125}$ Confusión para los acreedores(iii), ante el posible destino de

${ }^{120}$ A este respecto puede verse ya en el Derecho español alguna regulación sobre este aspecto. En el art. 39.3.III de la reciente Ley 2/20II, de Economía Sostenible, y también en el ámbito autonómico, de manera más detallada, el art. 7 de la Ley I5/20I0, de 9 de diciembre, de responsabilidad social empresarial en Extremadura (DOE, I5.I2.20IO).

${ }^{\text {I2I }}$ Vid. . Turner, A., Capital justo. La economía liberal, tr. esp., Barcelona, 2003, p. 354.

${ }^{\text {I22 }}$ Cfr. Olcese Santonja, A., en Real Academia de Ciencias Económicas y Financieras, dir. A. Olcese Santonja, cit., p. 35 ss., esp. 80-82 y 6I7 ss. (www racef.es). También, del mismo autor, El capitalismo humanista, cit., p. 287 ss.

${ }^{123}$ Vid. Bogle, J.C., La batalla por el alma del capitalismo, tr. esp., Madrid-Barcelona, 2007, p. 80-82: «Siempre se ha ejercido presión sobre los auditores para que formen sus opiniones de conformidad con las compañías clientes que pagan sus servicios. Pero a lo largo de la última década, a este aparentemente inevitable conflicto de interés se ha sumado el conflicto de estar vinculados a sus clientes al prestar servicios de consultoría de gestión al equipo directivo, por los que a menudo cobraban cantidades que eclipsaban los honorarios por auditorias. Por ejemplo, en el año 2000 las compañías norteamericanas pagaron a sus auditores cerca de 3000 millones de dólares por servicios de auditorías, sólo la mitad de los 6000 millones \$ pagados por servicios de consultoría. Los ingresos por servicios distintos de los de auditoría con seguridad constituían una proporción aún mayor en los beneficios netos de estas firmas.»

${ }^{124}$ Para el Comisario europeo de Mercado Interior -Charlie McCreevy-, resulta «pasmoso» que más de seis meses después del inicio de las turbulencias financieras en Europa todavía no se pueda conocer con exactitud el alcance de las mismas, debido, a la opacidad de las entidades crediticias. Aludió, especialmente, al papel de las agencias de calificación de riesgos, cuya tardanza en alertar sobre las dificultades con las hipotecas subprime en EEUU ya fue puesto de manifiesto el verano pasado; así como a la necesidad de revisar la función de dichas agencias de rating, de manera que si no mejoran su código de actuación, lo tendrá que hacer[la ley] la propia Unión Europea (Cfr. Diario El Mundo, viernes 8 de febrero de 2008, p. 39).

${ }^{125}$ Cfr. Moneva Abadía, J.M., «La información sobre responsabilidad social de la empresa en el contexto de la reforma contable», en AAVV, Responsabilidad social corporativa. Aspectos jurídico-económicos, Castelló de la Plana, 2005, p. I8I-2I3, esp. 208-209, respecto a la verificación de la información no financiera, entre otras cosas positivas y negativas, se nos dice lo siguiente: «El debate se plantea en dos aspectos: ¿quién debe realizar esa labor?, y ¿qué estandar deben utilizarse? Respecto a la primera pregunta, la respuesta es francamente difícil, ya que la profesión auditora no parece estar dispuesta a presentar servicio por la gran incertidumbre sobre los elementos que la componen: datos sociales y medioambientales. En cuanto a la segunda cuestión, ya existen instituciones relevantes que han realizado propuestas para verificar los informes de sostenibilidad...» 
recursos a finalidades no productivas. Y confusión también, finalmente, para los administradores sociales(iv), que se pueden ver sometidos a un juego contradictorio de directrices en orden a la gestión diligente de la empresa, tal y como exigen los artículos 225 y siguientes del Texto Refundido de la Ley de Sociedades de Capital(LSC) o del mismo modo otras disposiciones comparadas equivalentes. Lo que aconseja que la RSC/RSE no deba ser considerada ni como fuente de obligaciones, ni como fuente de responsabilidad de los administradores. ${ }^{\mathrm{I} 2}$ En este último caso la cuestión sí que esta directamente conectada con la concepción que se tenga sobre el interés social.

En conclusión, hay que partir, para evitar confusiones groseras, de que al menos en las zonas más desarrolladas del planeta -entendido esto tanto desde el punto de vista político como económico-, lo procedente, de utilizar el marchamo de empresa [socialmente] ${ }^{127}$ responsable, sería colocárselo a todas aquellas empresas que cumplen fielmente con la ley. ${ }^{128}$ Porque sólo de esta manera evitaremos caer en el error, igualmente grosero y perverso, de desplazar el deber(o si se quiere la responsabilidad) legal derivado del Estado democrático de derecho en favor de un «seudodeber» autoimpuesto y dependiente de las propias Corporaciones privadas: «Nadie debe dar por hecho que la supervisión llevada a cabo por consejeros y accionistas es suficiente. Los remedios y las salvaguardias deben poseer la fuerza de la ley. ${ }^{229}$ Con todos los peligros y problemas que este desplazamiento del poder de establecer normas comporta desde el punto de vista de la legitimidad. Y no estamos hablando de algo futurible, sino que es algo que ya está sucediendo respecto a algunos sectores normativos, ${ }^{130}$ como es el caso del Derecho contable por lo que se refiere al mundo empresarial. ${ }^{\mathrm{III}}$ De ahí que, como se nos dice respecto a la Francia de los últimos años, el orden decisivo jurídico-político, el único que permite la influencia del orden moral sobre el orden tecnocientífico(como, por ejemplo, la economía), se ha devaluado y desprestigiado de tal modo, a consecuencia de que no se valora suficientemente ni la fuerza de la economía, ni la debilidad de la moral, porque «cuanto más lúcido se es sobre la economía y sobre la moral(..), más exigente se es sobre el derecho y la política». ${ }^{\mathrm{I3}}$

En definitiva, téngase en cuenta que el soft law se califica de acuerdos formalmente normativos, pero que no son vinculantes, que presentan como problema fundamental el del sometimiento a ellos. Suelen incorporan exigencias morales y ponen en el escenario de la deliberación pública informaciones y opciones éticas importantes, lo que les hace que estén dotados de cierta auctoritas por su elaboración independiente y experta. Y en este sentido pueden ser un cauce muy interesante de orientación del debate público y una apelación al

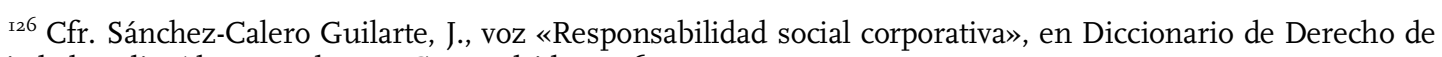
Sociedades (dir. Alonso Ledesma, C.), Madrid, 2006, p. I023 ss., esp. I025.

${ }^{127}$ La imprecisión del término es de tal calibre que lo mejor sería omitirlo (Cfr. Capron, M./QuairelLanoizelée, F., La responsabilité sociale d'entreprise, Paris, 2007, p. 28; Sánchez-Calero Guilarte, J., voz «Responsabilidad social corporativa», en Diccionario de Derecho de Sociedades, dir. Alonso Ledesma, C., Madrid, 2006, p. I025).

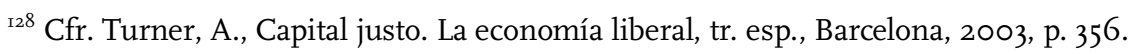
p. 86.

${ }^{129}$ Cfr. Galbraith, J.K., La economía del fraude inocente. La verdad de nuestro tiempo, tr. esp., Madrid, 2004,

${ }^{130}$ El caso de la investigación biomédica es especialmente significativo[Nos remitimos de nuevo a Monnier, S. Les Comités d'ethique et le droits. Eléments d'analyse sur le systéme normativif de la bioéthique, cit., p. 9I93; y Cabanillas Sánchez, A./Zavala, J., «El principalismo y su influencia en la normativa española sobre investigación biomédica», cit.

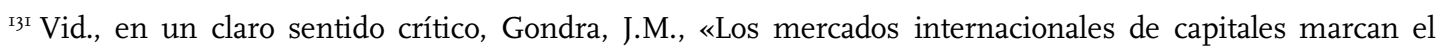
rumbo del derecho europeo de balances: ¿Hacia dónde nos llevan?», en AAVV, Responsabilidad social corporativa. Aspectos jurídico-económicos, Castelló de la Plana, 2005, p. 99-I8I.

${ }^{132}$ Comte-Sponville, A., El capitalismo, ¿Es moral?, cit., p. I5I. Para una buena aproximación a la situación político-social francesa de los últimos años, puede verse De Ménil, G., Common sense. Pour débloquer la société française, París, 2007, passim, esp. p. I77 ss. 
consumidor para que castigue con su conducta la inobservancia de ciertas pautas que se consideran correctas. Pero, a pesar de todo, el soft law no puede ser un vehículo idóneo para realizar el ideal del imperio de la ley porque no se presenta ante sus destinatarios en los mismos términos que el hard law. Este exige conformidad, mientras que las normas de soft law son de adhesión voluntaria y la conformidad con ellas está siempre condicionada. ${ }^{133}$

\section{VII. Ética empresarial y filosofía moral comunitarista: la extraña paradoja de la Tercera Vía. La Ley es el puente entre la actividad mercantil y la salvación del alma}

La ética empresarial, o la RSC/RSE, tienen el enorme mérito de llamar la atención del mundo económico sobre algunos valores esenciales, especialmente sobre la dignidad del hombre. ${ }^{\mathrm{I} 4}$ Así se hace especialmente desde la denominada Tercera Vía y del comunitarismo, y su búsqueda de la buena sociedad, cuando se habla de que las personas deben ser tratadas como fines en sí mismas y no como meros instrumentos. Se intenta compatibilizar el Estado, el mercado y la comunidad, especialmente dar mayor relevancia a esta última en las sociedades modernas. Y se caracteriza porque no se está ante el socialismo estatista, ni ante el neoliberalismo del libre mercado; de modo que no se inclina ni a la derecha ni a la izquierda, sino que se sitúa entre las concepciones del New Deal norteamericano, del gran Estado que administra programas sociales a gran escala e interviene ampliamente en la economía y el laissez-fair de un mercado sin restricciones. ${ }^{135}$ Ni un control exagerado y puntilloso de la economía y de la sociedad por el Estado, ni un mercado sin frenos. De modo que el Estado debe ser aligerado de peso, pero también existen muchas tareas que debe mantener, como la seguridad pública, la seguridad jurídica, la salud pública, la regulación del mercado, tanto para favorecerlo, como para garantizar un sentimiento básico de seguridad económica. Debe también expandir el trabajo disponible, incluso, si es necesario, mediante el reparto del trabajo; debe compartir las cargas medioambientales con las empresas; y como norma general el Estado no debe ser la primera fuente de servicios sociales(pequeños créditos, cuidado de niños o enfermos, etc), porque el Estado que se convierte en la fuente principal o única de estos servicios, minusvalora, desmoraliza y burocratiza relaciones que están en el núcleo de la vida de la comunidad. Pero desde el comunitarismo no se duda en ningún momento de que el mercado es el mejor motor para la producción de bienes y servicios, para el trabajo, y para el empleo y el progreso económico. Y esto a pesar de los problemas sociales generados por el propio mercado, porque tales problemas no desmerecen a los méritos de un fuerte crecimiento económico. ${ }^{136}$ En definitiva, no se quiere vincular a ningún país ni cultura y sus raíces se dicen que son diversas y pluriculturales: Antiguo y Nuevo Testamento, las enseñanzas de los clásicos griegos, los planteamientos asiáticos, musulmanes y judíos sobre la armonía y la responsabilidad para con los demás; el socialismo no doctrinario, llamado utópico; la doctrina de la iglesia; y muchos planteamientos más. Y todo esto se pretende alcanzar por medio del diálogo moral, una discusión en torno a valores, no entre expertos sino entre ciudadanos, con la pretensión de que la gente modifique su conducta, sus sentimientos $y$ sus creencias. ${ }^{137}$

Estos planteamientos comunitaristas nos retrotraen en el tiempo hasta el Renacimiento italiano y hacia uno de sus pensadores más excelsos, como lo fue Giovanni

\footnotetext{
${ }^{133}$ Así se expresa el profesor Laporta, F.J., El imperio de la ley. Una visión actual, Madrid, 2007, p. 262-263.

${ }^{134}$ Vid. Tourneau, Ph. Le, «Existe-t-il une morale des affaires ?», en AAVV, La morale et le droit des affaires, Paris, I996, p. 23.

${ }^{135}$ Vid. Etzioni, A., La Tercera Vía hacia una buena sociedad. Propuestas desde el comunitarismo, tr. esp., Madrid, 200I, p. I5 Ss.; esp. I9-2I, 56 ss.

${ }^{136}$ Ibid., p. 76-87.

${ }^{137}$ Ibid. p. I9-20 y 6I-68.
} 
Pico della Mirandola, considerado por Tomás Moro, como el representante y paradigma del hombre moderno, y autor de uno de los más nobles legados de la cultura renacentista, ${ }^{1{ }^{8} 8}$ la Oración o Discurso sobre la dignidad del hombre[1486], también conocida como «manifiesto del Renacimiento italiano» o «manifiesto del hombre moderno». Nuestro recuerdo del personaje y de su obra se debe a que los postulados de la Tercera vía y el comunitarismo evocan los pensamientos renacentistas. Por un lado, porque hace hincapié en el hombre y su dignidad, algo propio de los studia humanitatis del humanismo renacentistas, pero lo hace colocándolo en el frontispicio de su Discurso, y pone el acento no tanto en la universalidad del hombre como en su libertad:

«Constreñido por ningunos límites, de acuerdo con tu propio libre albedrío, en cuyas manos te hemos puesto, ordenarás por ti mismo los límites de tu naturaleza. Tendrás el poder de degenerar en las formas más bajas de la vida, que son bestiales. Tendrás el poder, que surge del juicio de tu alma, de volver a nacer en las formas más altas, que son divinas.» ${ }^{139}$

Y por otro, su obra se caracteriza por un sincretismo muy acusado sin que consiga llegar a una síntesis profunda: en la obra aparecen elementos muy diversos tomados del platonismo y del aristotelismo, de la cábala y de la magia, de la escolástica medieval, árabe, judaica y cristiana. Con la utilización de todas estas fuentes, no pretende Pico tanto mostrar su saber, como subrayar su convicción básica de que todos y cada uno de estos pensadores tenían una genuina participación en la verdad filosófica. ${ }^{\mathrm{I}{ }^{\circ} \mathrm{Y}} \mathrm{Y}$ algo de todo esto nos parece que hoy reverdece con el denominado comunitarismo. ${ }^{\text {I4I }}$

En realidad, a nuestro juicio, con el nuevo paradigma socio-político de la tercera vía, en buena medida no se hace otra cosa que recordar la tercera fórmula del imperativo categórico kantiano, la denominada fórmula del fin en sí mismo: «Obra de tal modo que uses la humanidad tanto en tu persona como en la persona de cualquier otro siempre a la vez como fin, nunca meramente como medio». ${ }^{122} \mathrm{Y}$ puede ser que a fuerza de insistir, estas verdades universales traspasen todos los estratos sociales y nos acaben insuflando a todos los grandes principios morales, de modo que la «voluntad buena» kantiana ${ }^{\mathrm{T} 43}$ nos sitúe en el camino de la buena sociedad. Y quizá también de esta manera, parafraseando a Pico della Mirandola,

${ }^{138}$ Así se expresa Jacob Burckhardt en su clásico sobre La cultura del Renacimiento en Italia[ı86o] (Ed. Edaf, tr. esp., Madrid, I982, p. 276).

${ }^{139}$ Como se ha dicho, estas palabras tienen un timbre moderno, y se cuentan entre los pocos pasajes de la literatura filosófica del Renacimiento que han complacido, casi sin reserva, a oídos modernos y aun existencialistas...[E]l canto de Pico sobre la dignidad del hombre ha sido escuchado a través de los siglos hasta nuestro tiempo, aun por aquellos que han sido sordos al resto del concierto de pensamiento renacentista, aun por los que se autonombran humanistas modernos, que han olvidado que la humanitas incluye, además de sentimientos amistosos, una educación liberal y alguna instrucción[Kristeller, P.O., Ocho filósofos del Renacimiento italiano (I964), tr., esp., Madrid, I996, p. 92-93].

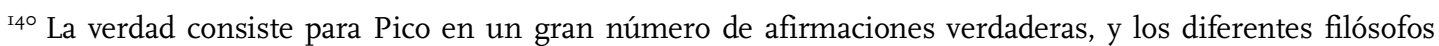
participan de la verdad en tanto que sus escritos contienen, al lado de numerosos errores, afirmaciones específicas reconocidas como verdaderas y que, por tanto, han de ser aceptadas....El sincretismo de los platónicos florentinos ha sido alabado con razón por varios historiadores como una pasarela hacía teorías posteriores de tolerancia religiosa y filosófica; Pico, al ensanchar el alcance y el contenido de ese sincretismo[incluye explícitamente a Aristóteles y sus seguidores griegos, árabes y latinos; y a los cabalistas judíos], puso las bases para una tolerancia más amplia[Kristeller, P.O., Ocho filósofos del Renacimiento italiano (I964), tr., esp., Madrid, I996, p. 83-85; También puede verse Garín, E., «El filósofo y el mago», en El hombre del Renacimiento, ed. E. Garín, tr. esp., Madrid, I990, p. I65 ss., esp. I8I-I82; Rico, F., El sueño del humanismo. De Petrarca a Erasmo, Barcelona, 2002, p. I52 ss.].

${ }^{\text {I4t }}$ Cfr. Etzioni, A., La nueva regla de oro. Comunidad y moralidad en una sociedad democrática, tr. esp., Barcelona, I999, passim.

${ }^{142}$ Kant, I., Fundamentación de la metafísica de las costumbres[I785], tr. esp., ed. de Luis Martínez de Velasco, Austral, I6 ed., Madrid, 2004, p. II5-II7 (Cfr., no obstante, Etzioni, A., La nueva regla de oro. Comunidad y moralidad en una sociedad democrática, tr. esp., Barcelona, I999, p. 286 ss.).

${ }^{143}$ Se considera como tal a aquella voluntad situada en un mundo inteligible en donde sólo se puede querer lo que concuerda con el deber moral (Kant, I., Fundamentación de la metafísica de las costumbres[I785], tr. esp., ed. de Luis Martínez de Velasco, Austral, I6ª ed., Madrid, 2004, p. I25-ı26). 
los saludables fármacos de la moral y de la dialéctica, traídos por el médico celestial Rafael, nos puedan curar. Y como de manera literal nos dice:

«Nosotros -los que anhelamos en la tierra la vida de los Querubines- debemos purificar nuestra alma de los impulsos de nuestras pasiones por medio de la ciencia moral. Debemos disipar la tiniebla de la razón con la dialéctica y expulsar las inmundicias de la ignorancia y de los vicios. De este modo, nuestros afectos no se desbocarán indómitos, ni nuestra razón insensata delirará insensatamente...En efecto, si la moral dirige la fuerza de los apetitos por sus cauces naturales según sus funciones; $y$ si la dialéctica mueve la razón haciéndola avanzar hacia su propio nivel $y$ medida, entonces, tocados por el arrebato de las Musas, regalaremos nuestros oídos con la música celeste.» ${ }^{\mathrm{I} 44}$

Pero las cosas no son tan sencillas, la vida es mucho más compleja. Con el modelo comunitarista, también denominado del «accionista estable», ${ }^{\mathrm{I}}$ se pretende humanizar el capitalismo pidiendo a los individuos y a las empresas(y en general a todo tipo de organismos) que asuman una mayor cantidad de responsabilidades, en el sentido de obligaciones o deberes morales. ${ }^{1{ }^{6} 6}$ Se trata de un nuevo frente contra el modelo liberal, propiciado más desde la «izquierda» ante su incómoda aceptación de la idea del «interés propio». Se pretende alcanzar una sociedad perfecta más allá de las leyes(impuestos, servicios colectivos, etc), recurriendo al convencimiento moral de los individuos(empresarios, directivos e inversores) de que gestionen sus empresas sobre una base más amplia de objetivos que los de máximos beneficios y el propio interés: se debe animar a las empresas a arriesgarse más en sus comunidades. ${ }^{147}$ Pero la buena voluntad, a veces, como sucede en este caso, está cargada de inconvenientes. Por un lado, resulta prácticamente imposible que las empresas puedan tomar en consideración en sus balances ese tipo de aspectos sociales. Ya resulta bastante difícil para las mismas solventar los problemas que la maximización de beneficios les presenta cada día, como para tener que enfrentarse a otro tipo de cuestiones sociales, para lo que no cuentan ni con los medios idóneos, ni estarán legitimadas en muchos casos para afrontar las necesarias negociaciones.

La enorme complejidad de las diferentes interacciones económicas y sociales hace inviable el modelo que se pretende, como sería en definitiva convertir a los individuos y sus empresas en los agentes efectivos de amplios objetivos sociales; además de que acabarían en meros voluntarismos generadores de confusión..$^{18}$ Hay por tanto que preservar el reparto de papeles entre el Estado(orden político-jurídico) y el mercado(orden económicoempresarial), entre el gobierno y los negocios, de modo que el primero con sus instituciones tiene la tarea de gobernar y el segundo de producir y distribuir. No hace falta insistir en la legitimidad del Estado para intervenir en la esfera económica, ya sea en un sentido o en otro, por razones de interés general. Estamos ante un orden social dividido y unido al mismo tiempo, la «insociable sociabilidad» de Kant, donde cada una de sus esferas responde a deberes o imperativos distintos, el interés individual frente al interés general. $\mathrm{Y}$ como nos recuerda Robert Heilbroner, ${ }^{149}$ Adam Smith comprendió con exactitud la cuestión al hablar de la Sociedad de la Libertad Perfecta y resaltar la independencia recién conquistada por su «mitad» económica:

I44 Pico della Mirandola, G., Oración o Discurso sobre la dignidad del hombre ( ${ }^{\circ}$ 5, 9 y I2)[1486], en Humanismo y Renacimiento, selección de P. R. Santidrián, Madrid, 2007, p. 24-25, I27-I30 y I3I Ss.

${ }^{145}$ Vid. Turner, A., Capital justo. La economía liberal, tr. esp., Barcelona, 2003, p. 353.

${ }^{146}$ Cfr. Etzioni, A., La Tercera Vía hacia una buena sociedad. Propuestas desde el comunitarismo, tr. esp., Madrid, 200I, p. 5I Ss. y 6I ss.

${ }^{147}$ Cfr. Turner, A., Capital justo. La economía liberal, tr. esp., Barcelona, 2003, p. 355 .

${ }^{148}$ Ibid. p. 356.

${ }^{149}$ Vid. Heilbroner, R., El capitalismo del siglo XXI, tr. esp., Barcelona, I996, p. 56-60. 
«Todo hombre, con tal que no viole las leyes de la justicia, debe quedar en perfecta libertad para perseguir su propio interés como le plazca, dirigiendo su actividad e invirtiendo sus capitales en concurrencia con cualquier otro individuo o categoría de personas. El Soberano[«el Estado»] se verá liberado completamente de un deber, cuya prosecución forzosamente habrá de acarrearle numerosas desilusiones, y cuyo cumplimiento acertado no puede garantizar la sabiduría humana ni asegurar ningún orden de conocimiento, y es, a saber, la obligación de supervisar la actividad privada, dirigiéndola hacia las ocupaciones más ventajosas a la sociedad.» ${ }^{150}$

En definitiva es de esta manera, con este juego permanente, y a veces arriesgado, entre lo general y lo particular, como se preserva la libertad. De ahí que la vía tradicional del cumplimiento del contrato $y$ de la ley, siga siendo la más adecuada. Por otro lado, como hemos anticipado, la buena voluntad del comunitarismo empresarial comporta el grave peligro de que al final no se haga nada. Que no se desarrollen las necesarias políticas jurídicas para solventar los problemas sociales mediante el medio más efectivo, como es la regulación legal. Como se ha dicho con toda claridad por A. Turner:

«[C]uanto más esperamos civilizar al capitalismo con vagas admoniciones a la responsabilidad empresarial y la ética comunitaria, más nos apartamos de la identificación y la puesta en marcha de esas intervenciones específicas -redistribución, oferta de bienes colectivos o regulación- que harían más humano el capitalismo. Y cuanto más empujen los gobiernos a las empresas a un esfuerzo conjunto para perseguir nobles propósitos de modo voluntario, menos dispuestos estarán a mantener su papel como defensores de los límites dentro de los cuales tienen que funcionar las empresas. La sociedad correcta aparecerá tras una fuerte tensión entre los límites políticamente definidos y el interés propio y el vigor de empresas y empresarios, y no siempre es prudente enturbiar esa división de papeles. El mayor deber social de las empresas es obedecer las leyes y pagar los impuestos que el gobierno impone.» ${ }^{\mathrm{II}}$

Pero de todo esto lo que más llama la atención es lo que se denomina la extraña paradoja de la tercera vía, y en cierto modo del socialismo, que parece preferir la confusa retórica del comunitarismo frente a la opción tradicional del liberalismo económico de faz humana o del Estado de bienestar. Y esto se viene a explicar por algunos, por lo difícil que resulta armonizar la apuesta por la empresa y el mercado, incluso a costa de ciertas políticas redistributivas, y paralelamente, apelar a un cierto sentimentalismo moral, moralizante en sentido estricto, que haga a la gente más cuidadosa y más humana individualmente. Lo que resulta claramente contradictorio. De ahí la paradoja y de ahí que se hable con cierto sarcasmo de la búsqueda del Santo Grial de la tercera vía, porque en realidad lo que se hace desde estas políticas, al menos en Europa, es continuar con mayor o menor intensidad, según los Gobiernos de turno, con la línea marcada desde hace algún tiempo de desarrollo de un capitalismo de rostro humano. ${ }^{152}$ En términos muy parecidos y con un fondo sustantivo análogo se ha planteado igualmente la denominada «paradoja de la stakeholder theory», ${ }^{53}$ por lo contradictorio que resulta para los gestores empresariales respetar una

${ }^{150}$ Smith, A., Investigación sobre la naturaleza y causas de la riqueza de las naciones[I776], tr. esp., México, FCE, sexta reimpresión, I990, p. 6ı2-6ı3. Sigue hablando A. Smith de los tres deberes de gran importancia que el Estado debe seguir cumpliendo: proteger a la sociedad de la violencia y la invasión, proteger a cualquier miembro de la sociedad de la injusticia y la opresión de otro miembro, y de erigir y mantener ciertas obras e instituciones públicas que la iniciativa privada no llevará a cabo, pero que son necesarias y compensa su gasto para una gran sociedad. No se trata del Estado del bienestar, pero refleja muy bien la división de planos o de ordenes a los que nos referimos (Cfr. Heilbroner, R., El capitalismo del siglo XXI, tr. esp., Barcelona, I996, p. 59).

${ }^{\text {I5I }}$ Vid. Turner, A., Capital justo. La economía liberal, tr. esp., Barcelona, 2003, p. 356 (La cursiva es nuestra).

${ }^{152}$ Ibid. p. 358-359.

${ }^{153}$ Vid. Goodpaster, K.E., «Business ethics and stakeholders analysis», Business Ethics Quarterly, I (I), I99I, p. $53-73$. 
lealtad multifiduciaria, que acaba poniendo en cuestión el derecho de propiedad de los accionistas.

Hay que recordar aquí a los defensores de los planteamientos comunitaristas, que ya en la Baja Edad Media se plantea un problema muy similar ante el conflicto entre la actividad mercantil precapitalista de los comerciantes y la moral cristiana de la época. Se trata de una cuestión enormemente interesante que viene a plantear la paradójica conexión entre la religión y el surgimiento del capitalismo. La pregunta que la gran mayoría de los medievalistas se han formulado es ¿cómo es posible que el comercio floreciese(spiritus capitalisticus) en un momento histórico en el que el sistema de creencias ponía el mayor énfasis en los aspectos místico y ascético de la vida y en las recompensas y castigos en el más allá? Sistema, además, apoyado por toda la autoridad moral y legal de una jerarquía eclesiástica omnipotente. Se han dado muchas explicaciones a este paradójico fenómeno social, pero lo cierto es que, como se nos dice, la Iglesia occidental de finales del XI y del XII, no sólo no denunció el dinero o las riquezas como tales, sino que en realidad alentó la búsqueda de dinero y riquezas, siempre que esa búsqueda se hiciera para ciertos fines y de acuerdo con ciertos principios. Así sucede con los gremios que asumen ciertas funciones religiosas y trasladan algunas normas morales a las transacciones comerciales. ${ }^{154}$ De esta manera se consigue que las actividades económicas de los mercaderes, como otras actividades de la época -caso de la actividad agrícola-, ya no sean vistas como un «peligro para la salvación», sino como un camino hacia la misma si se efectúan de acuerdo con los principios de la Iglesia desarrollados por el derecho canónico. Y así sucede con la lex mercatoria, ${ }^{155}$ que lo reflejaba y no lo contradecía. En definitiva, y es sobre lo que especialmente queremos llamar la atención, lo verdaderamente relevante es que la cuestión termina por solventarse con la encarnación en la ley de la moral social y económica que facilita la salvación de las almas de los comerciantes, de modo que la ley se constituye en un puente entre la actividad mercantil $y$ la salvación del alma. ${ }^{156}$

Por tanto, resulta hoy día muy sorprendente, y hasta cierto punto un tanto sospechoso, pretender imponer a los empresarios determinado tipo de exigencias morales al margen de la ley, cuando la experiencia y la historia nos enseña desde hace bastante tiempo que no es ese el camino, sino que es por medio de la ley como se deben articular y trasladar al mercado los postulados éticos o morales que se consideren más necesarios. Porque es de esta manera como se debe dar satisfacción al principio de seguridad jurídica. ${ }^{157}$ Pero bien entendido que esto no significa que todo deba estar regulado, ni que no se pueda exigir más que aquello que está expresa y concretamente mencionado en la ley o en el contrato. Lo primero, porque como ya nos dijera J.E.M. Portalis en su Discurso preliminar al Código Civil francés[I8or]: «Si se parte de la idea de que es preciso prevenir todo mal $\gamma$ todos los abusos de los que algunas personas son capaces, todo está perdido. Se multiplicaran las formalidades al infinito, no se dispensará más que una protección ruinosa a los ciudadanos; y el remedio llegará a ser peor que la enfermedad. ...Sin duda, no es que haga falta que los

${ }^{154}$ «El comercio legítimo basado en la buena fe debía distinguirse del comercio ilegítimo basado en la avaricia, y el comercio basado en la satisfacción de las necesidades legítimas debía distinguirse del comercio basado en el interés egoísta o en el dolo; los legítimos cargos por interés debían distinguirse de la usura; el precio justo debía distinguirse del precio injusto.» (Berman, H. J., La formación de la tradición jurídica de Occidente, tr. esp., México D.F., I996, p. 352-354). Sobre la elasticidad del Derecho canónico desde sus orígenes, la denominada aequitas canonica, con la distinción entre un ius divinum y un ius humanum, puede verse Grossi, P., Europa y el derecho, tr. esp., Madrid, 2007, p. 37-39 y 46 ss.

${ }^{155}$ Para una primera aproximación a la idea medieval de lex mercatoria nos remitimos a Berman, H. J., La formación de la tradición jurídica de Occidente, tr. esp., México D.F., I996, p. 349-373.

${ }^{156}$ Ibid. p. 355 .

${ }^{157}$ Dicho principio está recogido en el art. 9.3 de la Constitución Española y el Tribunal Constitucional español habla de seguridad jurídica como: la certeza sobre el ordenamiento jurídico aplicable y los intereses jurídicamente tutelados, o bien como la expectativa razonablemente fundada del ciudadano en cuál ha de ser la actuación del poder en la aplicación del derecho (SSTC, de 3 de enero de I986 y de I3 de abril de 2000). 
hombres puedan engañarse mutuamente cuando tratan entre sí; pero es preciso dejar alguna libertad a la confianza y a la buena fe. Las formalidades molestas e indiscretas desaniman el crédito, sin eliminar los fraudes; agobian $\sin$ proteger.» ${ }^{158} \mathrm{Y}$ respecto a lo segundo, complementario de lo anterior, porque el Derecho privado cuenta desde bien antiguo con una serie de deberes generales y normas supletorias que lo dotan de flexibilidad ${ }^{159}$ y de una cierta dosis de moralización de las obligaciones, como son los casos del principio general de buena fe y del deber de cooperación. ${ }^{160}$

\section{El fin de la empresa o de la sociedad mercantil: el interés social, la RSC/RSE y la responsabilidad de los administradores}

Hablar de la finalidad de la empresa es hablar del interés social de las sociedades mercantiles capitalistas, que como es sabido constituyen la forma más habitual de organizar las empresas por razones obvias de disfrute del beneficio de la limitación de la responsabilidad patrimonial. La cuestión del interés social es discutida y delicada. ${ }^{16 \mathrm{I}} \mathrm{La}$ LSC hace referencia al mismo en distintos preceptos pero sin concretar su verdadero alcance, fundamentalmente en materia de impugnación de acuerdos sociales en el artículo 204, y respecto al deber de lealtad exigible a los administradores según el artículo 226, donde el interés social se entiende como el interés de la sociedad. ${ }^{162}$ Especialmente nos interesa este último donde se establece la conexión entre dicho interés y la correcta actuación de los administradores, porque se plantea la importante cuestión sobre el interés que debe presidir la actividad gestora de los administradores y de ahí la posible exigibilidad de responsabilidades a los mismos(artículos 236 y ss.).

A nuestro juicio, la postura más acertada y coherente con nuestro sistema económico es la que considera que en las sociedades mercantiles el interés social debe estar representado por el interés de los accionistas, y no por otro tipo de intereses ajenos a los propietarios de la empresa, como son los denominados grupos participantes o partes interesadas(stakeholders). De estas dos visiones del interés social la primera se aleja o se desmarca de la RSC/RSE, mientras que la segunda se aproxima hasta el punto de que la hace suya. Veamos con algo más de detalle cada una de estas posiciones.

La primera se corresponde con la tradicional visión contractual del interés social, se trata de una visión monista constituida por el interés común de los socios y sirve de pauta de referencia de la actuación del órgano de administración de la compañía. ${ }^{163}$ Entra dentro de dicho interés toda actuación que sea concorde con la causa contractual, ya sea alcanzar los mejores niveles de producción, de beneficios o de dividendos. Y quedan fuera los intereses extrasociales. Como es natural siempre hay que contar con el margen de discrecionalidad propio del órgano de administración. La importada regla anglosajona del

\footnotetext{
${ }^{158}$ Portalis, J.E.M., Discurso preliminar al Código Civil francés[I8or], tr. esp., Madrid, I997, p. 98 (la cursiva es nuestra).

159 Vid. Carbonnier, J., Derecho flexible. Para una sociología no rigurosa del Derecho, tr. esp. de L. DíezPicazo, Madrid, I974, passim; Zagrebelsky, G., El derecho dúctil. Ley, derechos, justicia, tr. esp., Valladolid, I995, passim.

${ }^{160}$ Vid. Díez-Picazo/Roca Trias/Morales, Los Principios del Derecho Europeo de Contratos, Madrid, 2002, p. I55-I59.

${ }^{16 I}$ Vid., para una primera aproximación conectada con nuestro objeto de estudio y con referencias a otros autores, a Embid Irujo, JM, «La responsabilidad social corporativa ante el Derecho mercantil», cit., p. 24 ss.; Sánchez-Calero Guilarte, J. voz «Interés social», en Diccionario de derecho de sociedades, dir. C. Alonso, Madrid, 2006, p. 709 ss.

${ }^{162}$ Cfr. Broseta/Martínez Sanz, Manual de Derecho mercantil, I, I7ª ed., Madrid, 20Io, p. 428.

${ }^{163}$ Vid. Esteban Velasco, G., «Interés social, buen gobierno y responsabilidad social corporativa», cit., p. 25 SS. y 3I SS.
} 
«buen juicio empresarial» (business judgment rule) otorga cierto margen de maniobra respecto a la opción por políticas de corto, medio o largo plazo, expansionistas o retributivas, etc. Y esto sin perjuicio de los instrumentos legales de control que los accionistas tienen a su disposición(designación, revocación, remuneración, aprobación de cuentas, exigibilidad de responsabilidades). Los intereses extrasociales pueden estar tanto relacionados con la actividad empresarial como no relacionados. Sobre los segundos resulta evidente que están al margen del interés social, como pueden ser por ejemplo los relacionados con fines culturales, caritativos o filantrópicos. Y respecto a los primeros son los relativos a los sujetos que mantienen algún tipo de vinculación con la actividad social, como sucede con los trabajadores de la empresa, los proveedores, los acreedores, los clientes, los consumidores en general y ciertos intereses públicos. En estos casos los diferentes intereses en juego tienen su propio cauce de solución a través del mercado y de la regulación específica correspondiente, porque se trata de intereses de terceros. Su cauce natural será el contrato que vincule a la sociedad con el tercero, el derecho concursal, de responsabilidad civil, etc. Incluso en algunos casos por medio de normas societarias dirigidas a proteger a los terceros-acreedores, como sucede con las normas sobre el capital social, la disolución y la responsabilidad de los administradores. En definitiva lo relevante aquí es que estos intereses no pueden ser canalizados por la vía del interés social. Más modernamente esta visión contractual del interés social se ha reformulado hacia la idea de creación de valor para el accionista(shareholder) en el marco del buen gobierno societario(corporate governance). En este sentido la cláusula del interés social constituye un instrumento de integración del contrato de sociedad en favor de los inversores del capital que son los socios: maximizar el valor de la empresa y por tanto de las inversiones. ${ }^{164}$ Los demás intereses conectados a la actividad empresarial al igual que antes tienen sus propios mecanismos de protección. Y esta idea del interés social la hemos visto reflejada en los Códigos de buen gobierno que han ido apareciendo en España lo largo de lo últimos años: Código Olivencia, Informe Aldama y Código Unificado de Buen Gobierno Corporativo. ${ }^{\mathrm{I} 5}$

La segunda se corresponde con la también tradicional visión institucionalista de la empresa. Se trata de una visión pluralista sobre el interés de la empresa que entiende que en su seno no sólo tienen cabida los intereses de los inversores, sino que deben acogerse igualmente otro tipo de intereses de grupos implicados con la actividad empresarial, como son los casos de los trabajadores, o de los intereses generales del pueblo o del Estado. Esta idea se presenta inicialmente en Alemania por obra de Walter Rathenau en I9I7 bajo la idea de la Unternehmen an sich(el interés de la empresa en sí), que acaba convirtiéndose en una palabra mágica y generadora de una fuerte polémica. Con esta fórmula hay que señalar que inicialmente sólo se pretendía salvar los conflictos entre los diferentes intereses entre los distintos tipos de accionistas(empresarios, inversores y especuladores), para lo que se crea un interés superior a todos cuya gestión se niega a la junta general y se asigna al órgano de administración. ${ }^{166}$ Esta idea del interés social es cierto que tiene sus raíces en el primer tercio del siglo XX, en la Alemania socialista del período de entreguerras, se plasma legislativamente en su Ley de sociedades anónimas de I937, y después desaparece de la ley de I965, pero que no obstante, la doctrina y la jurisprudencia dominante de ese país han seguido manteniendo en cierto modo la visión institucionalista como una concreción de la

${ }^{164}$ Vid. Paz-Ares «La responsabilidad de los administradores como instrumento de gobierno corporativo», RdS, 20, 2003, p. 67 Ss., esp. I03-I04; idem, «La ley, el mercado y el gobierno corporativo», Ius et Veritas 24 (2002), p. I39-I4I; Alfaro Aguila-Real, Interés social y derecho de suscripción preferente, Madrid, I995, p. 5I Ss.; Sánchez-Calero Guilarte, J. voz «Interés social», en Diccionario de derecho de sociedades, dir. C. Alonso, Madrid, 2006, p. 7I2-7I3.

${ }^{165}$ Cfr. Grimaldos García, M.I., «Responsabilidad social corporativa y responsabilidad civil de los administradores», en AAVV, Responsabilidad social de la empresa y Derecho mercantil, dir. Alfonso Sánchez, R., Granada, 20I0, p. I55 Ss., esp. I57-I58.

${ }^{166}$ Vid. Fernández de la Gándara, L., La atipicidad en derecho de sociedades, Zaragoza, I977, p. 56-57; Esteban Velasco, G., El poder de decisión en las sociedades anónimas. Derecho europeo y reforma del derecho español, Madrid, I982, p. I23 ss., esp. I29-133. 
función social de la propiedad del artículo I4. II de la Ley Fundamental(GG). ${ }^{167}$ Pero hay que decir en honor a la verdad que la visión institucional o pluralista del interés social en el Derecho alemán de sociedades ha permanecido por obra de la ley y de manera muy limitada. ${ }^{168}$ Lo primero porque sólo se consolida a partir de 1976 con la Ley de cogestión, en realidad con la importante sentencia de I de marzo de I979 del Tribunal Federal Constitucional. ${ }^{169} \mathrm{Y}$ lo segundo, porque más que de pluralidad hay que hablar de dualidad o de pluralidad limitada, porque junto a los accionistas sólo se les da entrada a los intereses de los trabajadores y bajo un sistema infraparitario de codecisión. ${ }^{170} \mathrm{La}$ entrada de otro tipo de intereses(protección del medio ambiente, de los consumidores, etc.) sólo se hace posible por medio del difícil argumento del largo plazo, pero como es natural siempre conectado al beneficio para los accionistas. Pero nunca estarían justificadas las donaciones a las organizaciones políticas o sociales, ni la inversión de grandes cantidades para fines culturales o de otro tipo que no tengan relación alguna con el objetivo de la empresa. ${ }^{77 \mathrm{I}}$ De modo que la fórmula institucional tradicional sólo ha sido posible por la vía legal, para un reducido número de actores y también para un escenario muy limitado. Esto ha dado lugar a que la doctrina alemana tienda a concebir el «interés de la empresa» desde un punto de vista procedimental, o de legitimación por el procedimiento, no como el establecimiento de un rango material de importancia de los intereses a tomar en cuenta, sino, en el caso especial del consejo de vigilancia, como el establecimiento de deberes de conducta dirigidos a la colaboración y a la deliberación razonada de los conflictos y el ejercicio cooperativo de las facultades de dirección. ${ }^{172}$

En el momento presente, o mejor en los últimos años, y especialmente como consecuencia de algunos de los escándalos financieros que se han producido en el mundo ha reaparecido con cierta fuerza la vieja visión institucionalista del interés de la empresa en sí. Los numerosos excesos, ilegalidades y deficiencias de control que se han cometido bajo la moderna formulación de la visión contractual del interés social, como es la creación de valor para el accionista(shareholder), han contribuido sin duda a ello. Ahora la reaparición se ha producido bajo el ropaje de la RSC/RSE y de sus planteamientos éticos. ${ }^{173}$ Desde esta nueva

${ }^{167}$ Cfr. Kübler, F., Derecho de sociedades, tr. esp., Madrid, 200I, p. 290-29I.

${ }^{168}$ Cfr. Hopt, K.J., «¿Principios comunes de gobierno corporativo en Europa? Reflexiones sobre la influencia de los mercados de valores en las empresas y su regulación y sobre la convergencia del Common Law y el Civil Law en el Derecho de sociedades y el Derecho del mercado de capitales», en Hopt, K.J., Estudios de derecho de sociedades y del Mercado de valores, tr. esp., Madrid, 20I0, p. I35-I39. Entre nosotros puede verse a Esteban Velasco, G., El poder de decisión en las sociedades anónimas, cit., p. 28I ss.

${ }^{169}$ Cfr. Esteban Velasco, G., El poder de decisión en las sociedades anónimas. Derecho europeo y reforma del derecho español, Madrid, I982, p. 330-33I. También, Reich, N., Mercado y derecho, tr. esp., Barcelona, I985, p. 296-3Io; Gómez Segade, «Derechos de los socios, participación de los trabajadores y petrificación de la sociedad anónima», en Estudios Homenaje a A. Polo, Madrid, I98I, p. 307 Ss.

${ }^{170}$ Sobre el sistema alemán de cogestión hay que mencionar el intenso debate doctrinal actual que lo pone en cuestión, especialmente por la falta de competitividad de la sociedad anónima alemana frente a su homóloga europea. Se debate entre su abolición o su flexibilización, en este último sentido hacia un sistema participativo en la línea de lo establecido en la Directiva 200I/86/CE, sobre la implicación de los trabajadores en la sociedad europea (Cfr. Hopt, K.J., «La modernización del derecho de sociedades: perspectivas transatlánticas», en Hopt, K.J., Estudios de derecho de sociedades y del Mercado de valores, tr. esp., Madrid, 20I0, p. 279-280, que habla de que la Directiva europea sobre la implicación de los trabajadores constituye una victoria pírrica para Alemania; Zabaleta Díaz, M., «La simplificación del Derecho de sociedades en el marco de la competencia de los mercados y de la competencia entre ordenamientos: el caso alemán», en AAVV, Simplificar el Derecho de sociedades, dir. S. Hierro Anibarro, Madrid, 2010, p. I30-135)

${ }^{17 \mathrm{I}}$ Vid. Kübler, F., cit., p. 29I.

${ }^{172}$ Cfr. Kübler, F., cit., p. 673-674. Entre nosotros puede verse Rivero Lamas, J., Limitación de los poderes empresariales y democracia industrial, Zaragoza, I986, p. 77-78, con referencias a N. Luhmann.

${ }^{173}$ Claramente en este sentido, entre nosotros, Esteban Velasco, G., «Interés social, buen gobierno y responsabilidad social corporativa (algunas consideraciones desde una perspectiva jurídico-societaria)», cit., p. 47 Ss.. También Embid Irujo, JM, «La responsabilidad social corporativa ante el Derecho mercantil», cit., p. II Ss., esp. 24 ss. 
visión se pretende hacer ver que el interés social de la compañía va más allá de los accionistas, y de los trabajadores, y alcanza a cualquier posible beneficiario de una actividad empresarial socialmente responsable: los acreedores, proveedores, clientes, consumidores, el medio ambiente, las administraciones públicas, etc., en definitiva los denominados stakeholders. Pero en realidad lo que se hace no es más que volver sobre la vieja cuestión del conflicto entre el corto y el largo plazo, entre el aplazamiento del reparto de beneficios hoy para garantizar la estabilidad empresarial a largo plazo. Hay que decir que se trata de un dilema muy difícil que sólo se debe plantear en situaciones extremas donde esté en juego la propia supervivencia de la empresa. Así se puede deducir en cierto modo del artículo 254 de la LSA alemana, referido a la impugnación del acuerdo de distribución de los beneficios según balance, donde se establece indirectamente, sobre la base del criterio del buen juicio empresarial, el destino del resultado positivo empresarial a reparto de beneficios(un mínimo del $4 \%$ del capital social) entre los accionistas salvo razones de extrema gravedad. Hay que tener en cuenta, además, que el interés a medio plazo de los accionistas, unido a la regla del buen juicio empresarial(business jugment rules), cubre prácticamente todas las actividades del órgano de administración a favor de los trabajadores. Incluso cabe dar entrada también por esta vía a algunas de las iniciativas típicas de la RSC/RSE, como posibles donaciones, creación de fundaciones o medidas medioambientales. No se debe desconocer que estas actuaciones pueden beneficiar a los propietarios del capital. Pero de lo que no cabe duda es de que respecto a dichas actuaciones, amparadas en un concepto tan amplio del interés social, existe el enorme riesgo de que los administradores actúen en su propio interés. ${ }^{174}$

Hay que mencionar también dentro de las novedades legislativas más recientes el nuevo Derecho inglés de sociedades, donde aparece una novedosa regulación del interés social en sentido pluralista y muy en la línea de la RSC/RSE. Se trata concretamente de la sección I72 de la Company Act 2006, donde se establece que los administradores deben tener en cuenta las consecuencias a largo plazo de sus decisiones, actuar de buena fe, promoviendo el éxito de la compañía en beneficio de todos sus miembros. Se trata probablemente del deber más difícil asignado al administrador que debe pensar a la vez en los intereses de los socios, los empleados, proveedores, consumidores, clientes, terceros y también en el impacto de su actividad sobre el medio ambiente y el cuidado de mantener la «reputación ética» de la sociedad. Esta nueva fórmula ha provocado cierta inquietud entre los administradores de las grandes compañías. Pero normalmente en la práctica inglesa la gestión se focaliza únicamente en interés de los accionistas y no resultará nada fácil un comportamiento imparcial teniendo en cuenta que son los accionistas los que reeligen a los administradores. No obstante, desde hace algunos años existe una corriente jurisprudencial que da entrada a los intereses de los acreedores en concurrencia con los de los accionistas o incluso de manera preferente, pero bien entendido que bajos ciertas circunstancias especiales. Concretamente cuando se está ante situaciones de insolvencia o próximas a la insolvencia, se viene a decir que los intereses de la compañía son verdaderamente los de los acreedores existentes en ese momento. ${ }^{175} \mathrm{O}$ incluso que los accionistas dejan de ser los principales dueños de la empresa y en su lugar lo son los acreedores. Pero no van a disponer de una acción directa frente a los administradores, porque existen múltiples razones en el Derecho inglés para no conceder una acción de este tipo. ${ }^{176}$ En consecuencia, como los administradores no tienen un deber directo frente a los acreedores, estos últimos deben esperar al nombramiento de un liquidador o administrador concursal, que será quien podrá

${ }^{174}$ En este sentido Hopt, K.J., «¿Principios comunes de gobierno corporativo en Europa? Reflexiones sobre la influencia de los mercados de valores en las empresas y su regulación y sobre la convergencia del Common Law y el Civil Law en el Derecho de sociedades y el Derecho del mercado de capitales», cit., p. I36.

${ }^{775}$ Sobre todo esto con más detalle nos remitimos a Brunet, D., «La protección de los acreedores y la responsabilidad de los administradores en el Derecho inglés», Derecho de los Negocios, julio-agosto, 20II, p. 5 ss. También, Viñuelas Sanz, M., Responsabilidad por obligaciones sociales y responsabilidad concursal, Valencia, 20II, p. I25-I52.

${ }^{176}$ Ibid. 
entablar la correspondiente demanda en nombre de la sociedad para recobrar las propiedades, bienes o dinero, con el objetivo de incrementar la cantidad a devolver a los acreedores. En definitiva en el Derecho inglés de momento el único interés tutelado, además del interés de los accionistas, es el de los acreedores y bajo una circunstancias muy especiales como son las situaciones de insolvencia o próximas a la insolvencia, de modo que la tutela se lleva a delante por medio del Derecho concursal, lo que evidencia que se está ante la simple aplicación de la ley en sentido amplio y ante un ámbito tutelar subjetivo muy limitado. Habrá que esperar a la interpretación que hagan los tribunales ingleses de la nueva norma contenida en el artículo I72 de la Company Act 2006.

A nuestro juicio, la visión institucional del interés social, más allá de los planteamientos legales o procedimentales, que hemos mencionado como típicos del Derecho alemán o inglés, no resulta plausible. Y especialmente cuando dicha visión institucional se presenta bajo el ropaje ético de la RSC/RSE, porque la visión tan ampliamente pluralista que ésta desarrolla otorga un margen de discrecionalidad a los administradores insoportable para el sistema jurídico societario, hasta el punto que haría prácticamente imposible el control sobre la adecuación de su gestión a la cláusula del interés social. Es más se podría decir que dicha cláusula sería innecesaria a estos efectos. Lo que se dice se manifiesta en un doble sentido y en direcciones opuestas. Por un lado, porque daría cobertura a todo tipo de decisiones de los administradores, incluso en claro perjuicio de los intereses de los inversores. De modo que las actuaciones éticas en la línea de la RSC/RSE podrían ser utilizadas como coartadas exonerativas frente a las posibles acciones de responsabilidad. Y por otro lado, porque esas mismas actuaciones propias de la RSC/RSE no pueden ser exigidas a los administradores en ningún caso, porque no se trata de una responsabilidad en sentido jurídico, sino ante una actuación voluntaria de la empresa que no constituye un presupuesto de derechos individuales o colectivos de ningún tipo. ${ }^{177}$ Todo lo más a lo que se podría aspirar, según algunos autores defensores de la RSC/RSE, aunque tampoco compartimos esa idea por algunas de las razones desarrolladas a lo largo del presente trabajo, es a que se imponga a los administradores la necesidad «cumplir o explicar» (comply or explain) en la línea de los Códigos de Buen Gobierno Corporativo, de modo que pase desde el corporate governance a la RSC. ${ }^{178}$

Para terminar se viene a decir con mucha razón, a nuestro juicio, que ese interés de los accionistas, como finalidad de la empresa, es justamente lo que permite la diversidad de intereses. ${ }^{179} \mathrm{Y}$ es así que la empresa suele perseguir por lo general como fin último el lucro, en el sentido tradicional subjetivo de reparto de los beneficios, lo que resulta completamente lícito, pero también puede suceder que la finalidad de la empresa no sea exclusivamente el lucro, si así se establece expresamente en los estatutos. Puede tener otro tipo de fines, o puede matizar esa finalidad del beneficio mediante otro tipo de finalidades no dirigidas exclusivamente al lucro. Por ejemplo, la permanencia en el mercado, la conservación de la empresa para transmitirla o para legarla a los herederos, o para que se conserve la empresa familiar. Y esa preservación de la empresa, esa finalidad conservativa de la empresa, puede ser que en algunos casos amortigüe de manera considerable la finalidad lucrativa, o sencillamente que se compagine con fines filantrópicos $o$ humanitarios. Pero sea como sea, lo verdaderamente importante aquí es que la decisión corresponde a los propietarios de la empresa que son los accionistas, sin perjuicio de los Derechos que permiten o establecen una cierta participación en los órganos sociales de sujetos no inversores vinculados con la empresa.

${ }_{177}$ Claramente en este sentido Sánchez-Calero Guilarte, J. voz «Responsabilidad Social Corporativa», en Diccionario de derecho de sociedades, dir. C. Alonso, Madrid, 2006, p. I023 ss., esp. I028.

${ }^{178}$ En este sentido Embid Irujo, JM, «Derecho, mercado y responsabilidad social corporativa», en Papeles de Economía Española, Io8, «Responsabilidad Social Corporativa», 2006, p. 63 ss., esp. 66.

${ }^{\text {I79 }}$ Vid. Comte-Sponville, El capitalismo, ¿Es moral?, tr. esp., Barcelona, 2004, p. 234-235. 


\section{El valor de la ética empresarial: «el poder de la moral será siempre precario»}

No obstante, sin perjuicio de nuestras críticas anteriores, que entendemos justificadas, no queremos terminar sin realizar un pequeño canto a la esperanza. Pero debemos ser realistas, como por otra parte nos enseñaron los sofistas, ${ }^{180}$ y la realidad nos pone de manifiesto, que hoy en día, como nos dice el prof. Stiglitz, ${ }^{18 \mathrm{r}}$ todas las empresas, incluso las que más contaminan y las que peor tratan a sus trabajadores, contratan los servicios de empresas de relaciones públicas que aireen su sentido de la responsabilidad y su preocupación por el medio ambiente y por los derechos de los trabajadores. Hasta el punto de que las corporaciones se han hecho adeptas a la manipulación de la imagen y han aprendido a hablar en favor de la responsabilidad social al tiempo que continúan soslayándola. De manera que -nos sigue diciendo-, por importante que pueda ser el movimiento de la RSE no es suficiente, hay que completarlo con una normativa más dura. Las empresas realmente comprometidas darán la bienvenida a las regulaciones que refuercen el código de conducta que apoyan en público, porque las protegerán de la competencia desleal de las que no se suman a la misma política y contribuirá a evitar que haya una carrera de mínimos(to the botton). Y en este sentido se hacen una serie de sugerencias legislativas. Por un lado, se sugiere limitar el poder de las corporaciones por medio del Derecho de la competencia, especialmente frente a la globalización de los monopolios, con una ley de competencia global y una autoridad global que la aplique. En este caso los modelos a seguir los constituyen el Derecho norteamericano y el Derecho europeo. Por otro, mejorar la gestión de las corporaciones, clarificando las obligaciones y las consiguientes responsabilidades de los administradores sociales, para que sepan a que atenerse, por ejemplo, en orden a la aplicación de las políticas de protección del medio ambiente incluso a costa de los beneficios distribuibles. Y en este mismo ámbito, responsabilizar a los ejecutivos de las empresas por sus acciones dañinas, dentro o fuera de la empresa, incluso con sanciones penales, ${ }^{182}$ a la vista de la ineficacia incentivadora para los gestores de las sanciones civiles, que quedan diluidas por el juego de las contramedidas negociadas con la propia empresa: la contratación de seguros que cubren incluso las posibles multas a los administradores ${ }^{183}$ No menos importante, también en este ámbito de la gestión de las empresas, es lo relativo a que las corporaciones acaben reparando los daños producidos, ya sea a sus trabajadores o al entorno. En este punto las leyes tienen que mejorar mucho. Ya sea para permitir que el dañado pueda demandar a la empresa dañante en el país donde se encuentra la sede de la corporación, y así solventar la probable insolvencia de la filial. O ya sea facilitando la ejecución de sentencias extranjeras en los países desarrollados. Algo similar a lo que sucede en el caso de los arbitrajes comerciales internacionales. Y también, sometiendo a las empresas a los tribunales de los países donde desarrollan su actividad y cometen las infracciones. Hay en toda esta problemática una cuestión jurídica de fondo relacionada con el Derecho de sociedades, más concretamente con los grupos de sociedades, como es la aplicación de la denominada doctrina del levantamiento del velo de la personalidad jurídica de las sociedades, que es aplicada en los ámbitos nacionales de los países desarrollados con

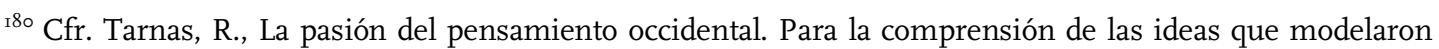
nuestra cosmovisión, tr. esp., Barcelona, I997, p. 4I-47.

${ }^{\text {I8I }}$ De quien tomamos lo que sigue (Vid. Stiglitz, Cómo hacer que funcione la globalización, tr. esp., Barcelona, 2006, p. 24I Ss., esp. 255 SS.).

${ }^{182}$ Cfr., también, Galbraith, J.K., La economía del fraude inocente. La verdad de nuestro tiempo, tr. esp., Madrid, 2004, p. 86.

${ }^{183}$ En este punto existen algunas novedades legislativas que vienen a paliar los excesos. En Europa, el nuevo artículo 93 de la Ley alemana de sociedades anónimas (Aktiengesetz) en su reforma de 2005, que establece una franquicia a cargo del administrador. Y en el derecho norteamericano, la Ley Sarbanes-Oxley, aprobada en 2002, bien que como reacción a los escándalos financieros ocurridos, pero con la clara finalidad de imputar al director general de la empresa la responsabilidad por la llevanza de la contabilidad (Para una primera aproximación a este texto legal y sus posibles efectos extraterritoriales nos remitimos a Lanois, P., L'effet extraterritorial de la loi Sarbanes Oxley, Paris, 2008, esp. p. 76 ss.). 
mayor o menor acierto, pero que está necesitada de regulación para su extensión a la economía globalizada. El prof. Stiglitz, ${ }^{184}$ con cierta visión jurídica, nos dice:

«La responsabilidad limitada no puede ser sacrosanta. Como los derechos de propiedad -y el de propiedad intelectual-, es una creación humana y tiene el propósito de proporcionar incentivos adecuados; y cuando no cumple con su función social, hay que modificarla.»

Se trata de una apreciación con la que podemos estar más o menos de acuerdo, pero bien entendido que la comunicación de la responsabilidad de las filiales a la empresa matriz no puede depender en exclusiva de la cuota de participación o del control, de la misma manera que no se puede hacer responsable al socio de control de una sociedad independiente por el simple hecho de serlo, sino que es necesaria la concurrencia de otro tipo de circunstancias específicas, que por lo general se dan con frecuencias en los grupos de empresas, como son las situaciones de infracapitalización, de confusión de esferas o de confusión de patrimonios. ${ }^{185}$

En resumidas cuentas se hace necesario contar con una legislación internacional y con la creación de tribunales de justicia internacionales, leyes globales para una economía global, que permitan las demandas conjuntas de los consumidores o de los colectivos perjudicados, bien por razones de competencia o bien por razones de daños. De la misma manera que hace falta atacar sin remilgos, igualmente con leyes, la corrupción y los sobornos(y el secreto bancario), ${ }^{\mathrm{I} 86}$ ya sea en su forma tradicional, o en la más moderna de los fondos para contribuciones de interés especial destinados a los partidos políticos, legisladores o funcionarios del gobierno a cambio de un trato especial. Porque pocas cosas resultan más corrosivas que la corrupción de las instituciones públicas, que permite la concentración de poder, que aquellos que detentan el poder económico se hagan también con el poder político. Amitai Etzioni, además de reconocer que la globalización reclama el desarrollo de instituciones políticas y sociales en todos los ámbitos, y de considerar empíricamente incorrecta y moralmente falsa la premisa de que la sociedad no puede responder a los efectos negativos de la globalización, nos llama la atención a los europeos, respecto a la pérdida de confianza social entre el público, y especialmente respecto a los líderes públicos en los Estados Unidos:

«El público norteamericano ha acabado por mostrarse particularmente cínico respecto a un sistema político en el que limitar el papel que juegan en la vida pública las aportaciones económicas privadas es casi imposible. Las sociedades europeas deberían prestar mayor atención a esta cuestión de la que han dedicado hasta ahora. Es cierto que los problemas pueden ser considerados como menos graves en los países de la UE que en muchas otras sociedades, pero también es cierto que «el mejor momento para echar la llave a la granja es antes de que nos roben los caballos». En Europa hay abundantes normas legales que pretenden impedir la corrupción de los políticos. Queda por ver si ello es suficiente para proteger la vida pública frente a la presión del poder económico privado.» ${ }^{\mathrm{I} 7}$

Además, no se puede dejar de recordar, que entre un lado y otro del Atlántico conviven dos formas distintas de organizar el Estado democrático de derecho. Más al oeste,

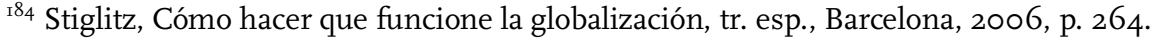

${ }^{185}$ Cfr. Paz-Ares, C., en Uría-Menéndez, Curso de Derecho Mercantil, I, $2^{\text {a }}$ ed., Cizur Menor, 2006, p. 598 6oI y I487-I489.

${ }^{186}$ «Cuando permite ocultar infracciones, el cacareado secreto bancario ya no tiene nada de legítimo, pues la ética no debe servir para proteger el fraude fiscal, el dinero del crimen o el del terrorismo» (Lipovetsky, G., Metamorfosis de la cultura liberal. Etica, medios de comunicación, empresa, tr. esp., Barcelona, 2003, p. 95).

${ }^{187}$ La Tercera Vía hacia una buena sociedad. Propuestas desde el comunitarismo, tr. esp., Madrid, 200I, p. 86 ss. y 93.
} 
como es sabido, impera una visión más liberal, menos intervencionista, ${ }^{188}$ donde se confía buena parte del auxilio social a la iniciativa privada, y donde, hasta cierto punto, se confía bastante en la divina providencia, esta vez disfrazada de RSC/RSE. Y esto se hace especialmente ostensible, quizás hasta escandaloso, si nos desplazamos hacia el mundo globalizado, donde como acabamos de ver a través de una de las voces más autorizadas de la ciencia económica, reina el desorden jurídico. De ahí que hoy día no resulte extraño encontrarnos con reflexiones tan elocuentes, como las que hablan de que los nuevos paradigmas de la mundialización se corresponden con un nuevo orden mundial y un nuevo desorden jurídico(The Paradigm Shifts of Globalisation: New World Order, New Legal Disorder). ${ }^{189} \mathrm{O}$ como de manera más gráfica lo calificó Anthony Giddens: un mundo desbocado. ${ }^{190}$ Por el contrario, en la Europa occidental, especialmente en el continente, las cosas vienen siendo de otro modo, y sobre la base de la cláusula del Estado social se ha confiado menos en la providencia y más en el imperio de la ley, que intenta alcanzar un cierto equilibrio entre libertad e igualdad. De ahí que, a nuestro juicio, en este caso, el recurso a la RSC/RSE resulta cuando menos mucho más chocante y, hasta cierto punto, peligroso, porque se puede convertir en un arma deslegitimadora de la ley; cuando es precisamente ésta, a pesar de todas sus crisis, ${ }^{191}$ el principal y fundamental instrumento de legitimación porque representa la voluntad general en el más puro y estricto sentido rousseauniano. ${ }^{192} \mathrm{Y}$, por otro lado, también hay que recordar que si bien desde planteamientos políticos de corte conservador o liberales resulta bastante más coherente el recurso a la ética empresarial, dado que ésta conlleva el desarrollo de la máxima liberal de menos Estado y más mercado; ${ }^{193}$ por el contrario, el grado de coherencia es mucho menor si nos situamos en el lado político de la izquierda o de la socialdemocracia, donde como es sabido no se confía tanto en la capacidad de autocontrol de la responsabilidad por parte de los operadores económicos, sino que más bien se aboga en favor de la regulación legal, o de la negociación en el terreno sindical, ${ }^{194}$ de las cuestiones básicas del mercado y del ciudadano. ${ }^{195}$ No obstante, esta bipolarización resulta en cierto modo también tópica, porque el imperio de la ley se defiende igualmente como uno de los pilares del orden liberal: la otra mitad del orden de la libertad junto al Estado nacional y la democracia parlamentaria. Y desde estos mismos planteamientos se critica a quienes reclaman la necesidad de confianza(trust) para el buen funcionamiento de un sistema jurídico, cuando

\footnotetext{
${ }^{188}$ Vid. Amin, S., El virus liberal, tr. esp., Barcelona, 2007, p. I5 ss. y 49 ss.

${ }^{189}$ Vid. Juvin, H., «Les nouveaux paradigms de la mondialisatio: Nouvel ordre mondial, nouveau désordre juridique/The Paradigm Shifts of Globalisation: New World Order, New Legal Disorder», RDAI/IBLJ, 5, 2007, p. 587 ss. También, Franchi, Fr. «Les enterprises face au désordre juridique: les manifestations internationals
} d'une nouvelle insecurité/Global Enterprise Faces Repressive Risks», RDAI/IBLJ, 5, 2007, p. 595 ss.

${ }^{190}$ Giddens, A., Un mundo desbocado. Los efectos de la globalización en nuestras vidas, tr. esp., Madrid, 2000, p. I9-3I. También puede verse, Amin, S., El virus liberal, tr. esp., Barcelona, 2007, p. 29 ss. , esp. p. 74 y 99 ss.

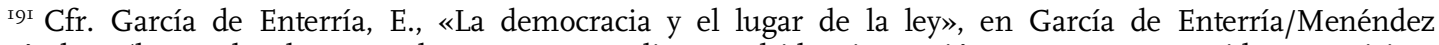
Menéndez, El Derecho, la Ley y el Juez. Dos estudios, Madrid, reimpresión 2000, p. I9 ss.; idem, Justicia y seguridad jurídica en un mundo de leyes desbocadas, Madrid, reimpresión 2000, p. 47-52; y Laporta, F.J., El imperio de la ley. Una visión actual, Madrid, 2007, p. I66-I67.

${ }^{192}$ Vid., J.-J. Rousseau, Del contrato social. Discursos, tr. esp., $2^{a}$ ed., en «El libro de bolsillo», Madrid, I982, p. 42-43 (Libro II, Capítulo VI). Entre nosotros, cfr. García de Enterría, E., «La democracia y el lugar de la ley», en García de Enterría/Menéndez Menéndez, El Derecho, la Ley y el Juez. Dos estudios, Madrid, reimpresión 2000 , p. I9 ss., esp. 52-57; idem, Justicia y seguridad jurídica en un mundo de leyes desbocadas, Madrid, reimpresión 2000, p. 23-28.

${ }^{193}$ Cfr. Rodríguez Braun, C., Estado contra mercado, Madrid, 2000, passim; Amin, S., El virus liberal, tr. esp., Barcelona, 2007, p. 15-27.

${ }^{194}$ Vid. Jiménez Fernández, J.C., La responsabilidad social de las empresas (RSE). Cómo entenderla, cómo afrontarla. Una perspectiva sindical, Albacete, 2007, p. 28-30.

${ }^{195}$ Cfr. Hobsbawm, E.J., Política para una izquierda racional, tr. esp., Barcelona, 2000, p. 7-I4; Giddens, A., Un mundo desbocado. Los efectos de la globalización en nuestras vidas, tr. esp., Madrid, 2000, p. 8I ss. ;Amin, S., El virus liberal, tr. esp., Barcelona, 2007, p. I20. 
en realidad es éste el que aporta aquélla, porque como se nos dice el mundo anómico(sin normas, sin asideros) no fomenta precisamente la confianza. ${ }^{196}$

A pesar de todo, el movimiento por la responsabilidad social de la empresa hace concebir esperanzas a personas tan prestigiosas, y dignas de todo respeto intelectual, como es el caso del Nobel de Economía Joseph E. Stiglitz, porque a su juicio son cada vez más las empresas que no quieren embarcarse en una carrera de mínimos y apoyan las leyes contra la corrupción. ${ }^{\mathrm{I} 97} \mathrm{O}$ a otros, con igual reconocimiento, como Gilles Lipovetsky, que les hace decir que a la ética de los negocios no se le puede exigir el desinterés, un virtuosismo imposible de llevar a cabo en el mundo económico, sino tan sólo el respeto de los principios más elevados del humanismo moral. Una ética modesta, pero que no equivale a una ética débil o nula, porque no podemos esperar más que eso del maridaje de la ética con los negocios. ${ }^{198}$ En definitiva, como se ve, y como hemos anticipado, una ética que por sí misma sólo tiene un alcance muy limitado: «el poder de la moral será siempre precario», 199 que como se nos dice, paradójicamente, se concreta en buena medida en el respeto a la ley. Que es precisamente de lo que se trata. Pero que en cualquier caso, lo verdaderamente importante para nosotros, es que de este modo se pone de manifiesto con cierta claridad la fragilidad y el autoengaño que supone esta pretendida nueva ética de los negocios que es la responsabilidad social corporativa.

${ }^{196}$ Vid. Dahrendorf, R., En busca de un nuevo orden. Una política de la libertad para el siglo XXI, tr. esp., Barcelona, 2005, p. I33; idem, El recomienzo de la historia. De la caída del muro a la guerra de Irak, tr. esp., Buenos Aires, 2006, p. 254 ss., esp. 257 ss.

${ }^{197}$ Stiglitz, J.E., Cómo hacer que funcione la globalización, tr. esp., Barcelona, 2006, p. 267-268. 96.

${ }^{198}$ Metamorfosis de la cultura liberal. Etica, medios de comunicación, empresa, tr. esp., Barcelona, 2003, p.

${ }^{199}$ Recordamos aquí las palabras ya citadas de Höffe, O, «El poder de la moral», cit., p. I26. 